William \& Mary Law School

William \& Mary Law School Scholarship Repository

$5-2019$

\title{
American Democratic Deficit in Assisted Reproductive Technology Innovation
}

Myrisha S. Lewis

Follow this and additional works at: https://scholarship.law.wm.edu/facpubs

Part of the Family Law Commons, Health Law and Policy Commons, and the Science and Technology Law Commons

Copyright c 2019 by the authors. This article is brought to you by the William \& Mary Law School Scholarship Repository.

https://scholarship.law.wm.edu/facpubs 


\title{
The American Democratic Deficit in Assisted Reproductive Technology Innovation
}

\author{
Myrisha S. Lewis \\ I. INTRODUCTION \\ II. SCIENTIFIC AND CONCEPTUAL BACKGROUND \\ A. AsSisTED REPRODUCTIVE TECHNOLOGY \\ B. DEMOCRATIC DEFICIT \\ III. REGULATORY BACKGROUND \\ A. UNITED KINGDOM \\ 1. THE UNITED KINGDOM'S REGULATORY FramEWORK \\ GOVERnING Assisted RePRODUCTIVE TECHNOLOGY USE \\ AND INNOVATION \\ 2. The United Kingdom's Public Consultation Related \\ TO A NEW FORM OF ASSISTED REPRODUCTIVE TECHNOLOGY \\ B. UNITED STATES \\ THE ROLE OF NON-GOVERNMENTAL BODIES \\ 1. The American Federal Regulatory FramewOrk \\ GOVERNING Assisted ReProductive TeChNOLOgy UsE \\ AND INNOVATION \\ 2. THE ROLE OF NON-GOVERNMENTAL BODIES \\ IV. IMPLICATIONS OF THE UNITED STATES' DEMOCRATIC DEFICIT \\ V. ADAPTING THE TOOLS OF ADMINISTRATIVE LAW TO MINIMIZE \\ THE U.S. DEMOCRATIC DEFICIT IN ASSISTED REPRODUCTIVE \\ TECHNOLOGY INNOVATION \\ A. An IndePEndent Federal Agency in The U.S. \\ B. Adapting The United Kingdom's Public Consultation on \\ Assisted Reproductive Technology to The U.S. Regulatory \\ REGIME \\ C. Greater Disclosure: Separating Scientific Concerns From \\ VI. CONCLUSION \\ POLITICAL AND ETHICAL CONCERNS
}

In many areas of innovation, the United States is a leader, but this characterization does not apply to the United States' position in assisted reproductive technology innovation and clinical use. This article uses a political science concept, the idea of the "democratic deficit" to examine the lack of American public discourse on innovations in ART. In doing so, the article focuses on America's missing public consultation in health care innovation. This missing discourse is significant, as political and ethical considerations may impact regulatory decisions. Thus, to the extent that these considerations are influencing the decisions of federal agency employees, namely those who work within the U.S. Food and Drug Administration, the public is unable to 
participate in the decision-making process. This lack of a public discourse undermines the goals of the administrative state, which include democratic participation, transparency, and accountability.

The United Kingdom, on the other hand, has had a markedly divergent experience with assisted reproductive technology innovation. Instead of ignoring the various ethical, social, and legal issues surrounding assisted reproductive technology innovation, the United Kingdom engaged in a five-strand public consultation on the topic of mitochondrial transfer, a form of assisted reproductive technology that uses genetic modification in order to prevent disease transmission. This article argues that after a multi-decade standstill in terms of the public discourse related to ethical issues associated with assisted reproductive technology and germline modification, it is time for the United States to institute a more democratic inquiry into the scientific, ethical, and social implications of new forms of assisted reproductive technology and ultimately, forthcoming medical innovations that involve genetic modification.

\section{INTRODUCTION}

The 2010 Nobel Prize in Physiology or Medicine was awarded to Robert G. Edwards "for the development of in vitro fertilization." In awarding the prize, the Nobel Committee noted that Dr. Edwards' "achievements have made it possible to treat infertility, a medical condition afflicting a large proportion of humanity including more than 10 percent of all couples worldwide."' Since the birth of the first child using in vitro fertilization (a form of assisted reproductive technology) in $1978^{3}$ in the United Kingdom, various strides have been made in assisted reproductive technology. Yet while the United States has been a leader in many domains of technological innovation and regulation, the same characterization does not apply to the United States' place in assisted reproductive technology ("ART"). ${ }^{+}$Most recently, forms of ART involving genetic modifications have been developed in both the United Kingdom and the United States. ${ }^{5}$ A number of media and scientific publications have noted that the United States

\footnotetext{
${ }^{\dagger}$ Assistant Professor, William \& Mary Law School; J.D., Columbia Law School; A.B., Harvard College. For helpful comments and suggestions, I would like to thank Aaron-Andrew Bruhl, Evan Criddle, Tara Grove, Lisa Ikemoto, Allison Orr Larsen, Sonia Suter, and participants at the 2019 American Journal of Lw and Medicine Symposium.

${ }^{1}$ Press Release, The Nobel Assembly at Karolinska Institutet, The Nobel Prize in Physiology or Medicine 2010 (Oct. 4, 2010),, https://www.nobelprize.org/prizes/medicine/2010/press-release/ [https://perma.cc/CK2M-NNJE].

${ }^{2} I d$.

${ }^{3}$ See Genelle Weule, First II F Baby's 40 Birthday: How a Tiny Girl Changed Science and the World, ABC NEwS (July 24, 2018), https://www.abc.net.au/news/science/2018-07-25/first-ivf-baby-louise-joy-browntums-40/10017032 [perma.cc/BK2Y-XAAY].

${ }^{4}$ For example, Professor Daniel Carpenter has observed that "the United States still houses the strongest of global pharmaceutical regulators" after being the first such regulator in the world. DANIEL P. CARPENTER,

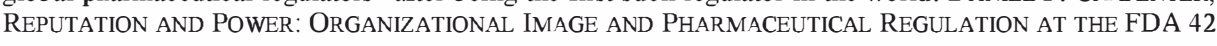
(2010).

${ }^{5}$ See Myrisha S. Lewis, How Subterranean Regulation Hinders Innovation in Assisted Reproductive Technology, 39 CARDOZO L. REV. 1239, 1242-44, 1247-51 (2018) [hereinafter Subterranean Regulation]. While the first child to be born using mitochondrial transfer was purportedly born in Ukraine, because there is no system of regulation in Ukraine, that country is not a subject of the comparative analysis in this Article. See Susan Scutti, Controversial II F Technique Produces Baby Girl -- and for Some, That's Problem, CNN (Jan. 18, 2017), https://www.cnn.com/2017/01/18/health/ivf-three-parent-baby-girl-ukraine-bn/index.html [https://perma.cc/DV2J-4CKH]; see also infra Part III (discussing U.S. and U.K. innovation in assisted reproductive technology).
} 
will lag behind the United Kingdom in ART development due to regulatory barriers that prevent the approval of a new form of ART, mitochondrial transfer, which combines in vitro fertilization with genetic modification in order to prevent the transmission of genetic disease. ${ }^{6}$

Newer forms of ART, such as mitochondrial transfer and cytoplasmic transfer, another form of ART used in the late 1990s that also combined traditional ART with genetic modification (also referred to as "advanced assisted reproductive technologies"), raise interesting federalism issues: the U.S. Food and Drug Administration ("FDA") has asserted jurisdiction over these forms of ART, meanwhile state law governs the practice of medicine and family formation. ${ }^{7}$ This article will examine the regulation of mitochondrial transfer in the United States and the United Kingdom, as well as the regulation of an earlier, similar technique of ART, cytoplasmic transfer. ${ }^{8}$ Research on that technique in the United States has been suspended since at least 2001, when the FDA sent letters threatening legal action to physicians researching the technique. ${ }^{9}$ The FD A's assertion of jurisdiction over in vitro fertilization ("IVF") practice in 2001, which is usually the subject of state regulation, had a negative impact on research and clinical use of other IVF techniques, including mitochondrial transfer. ${ }^{10}$ Also, by not addressing the safety and ethical issues related to cytoplasmic transfer in 2002, the United States

' Nina Bai, Three-Parent Babies: The Science of Replacing Mitochondrial DNA and What Remains Lnknown, UCSF NEWS CENTER (Jan. 17, 2017), https://www.ucsf.edu/news/2017/01/405486/three-parent-babiesscience-replacing-mitochondrial-dna-and-what-remains-unknown [perma.cc/8NCV-UBUU]; Steve Connor, Three-Parent Baby Pioneer: "The Brits Will be Ahe d of the World", THE INDEPENDENT (Jan. 17, 2015) ("At least the Brits get it. They will be ahead of the world. It's too bad it's taken so long. It could have been done 15 years ago. I put my toe in the water and got shark bite, so I'm done with it. It's too bad because it cramps creativity, it inhibits medical progress."') (quoting Dr. Jamie Grifo, and American researcher whose work on "three-parent in vitro fertilization" was halted by the U.S. Food \& Drug Admin.); Mitochondrial Donation Treatment, HUMAN FERTILISATION \& EMBRYOLOGY AUTH., https://www.hfea.gov.uk/treatments/embryotesting-and-treatments-for-disease/mitochondrial-donation-treatment/ [https://perma.cc/2AR8-MQDE].

"Three-parent in vitro fertilization" is the colloquial term for mitochondrial donation, which is also referred to as mitochondrial transfer, or mitochondrial donation therapy. See HUMAN FERTILISATION \& EMBRYOLOGY Auth., SCIENTIFIC REVIEW OF THE SAFETy AND EFFICACY OF METHOdS to Avoid MitochondRial Disease THROUGH AsSisted CONCEPTION: 2016 UPDATE 42, 57 (2016), https://www.hfea.gov.uk/media/2611/fourth_scientific_review_mitochondria_2016.pdf.

${ }^{7}$ For more on federalism, see Nicholas Bagley, Federalism and the End of Obamacare, 127 Y ALE L.J. FORUM 1, 2 (2017); Timothy Zick, Are the States Sovereign?, 83 WASH. U. L. Q. 229, 255, 292-94 (2005). For more on newer forms of ART, see Myrisha S. Lewis, Halted Innovation: The Expansion of Federal Jurisdiction Over Medicine and the Human Body, 2018 UTAH L. REV. 1073, 1100 (2018) [hereinafter Halted Innovation]; Subterranean Regulation, supra note 5, at 1241-45, 1248 ("A cell essentially contains three parts: cytoplasm, nucleus, and mitochondria. The nucleus, which is the center of the cell, is surrounded by cytoplasm. Mitochondria are located in the cytoplasm of the cell." (citations omitted)). Mitochondrial transfer and cytoplasmic transfer, two techniques of assisted reproductive technology, involve the modification of less than .0001 percent of DNA; however, the modification of DNA (even though it is not the "nuclear DNA" that dictates hair color and eye color for example), has led to opposition to the techniques. Mitochondrial transfer is currently being used to prevent the transmission of genetic disease whereas cytoplasmic transfer was used to improve fertility outcomes. Infra Part III.A.

${ }^{8}$ Connor, supra note 6; see Don P. Wolf et al., Mitochondrial Replacement Therapy in Reproductive Medicine, 21 TRENDS IN MOLECULAR MED. 68, 72 (2015) ("In 1998-1999, cytoplasmic transfer, or the augmentation of patient eggs with a small volume (1-5\%) of donor cytoplasm was used by several IVF clinics in an effort to overcome repeated IVF failures in selected patients. The procedure essentially involved co-injection of donor cytoplasm with sperm, as an extension of [intracytoplasmic sperm injection]. Several pregnancies were established before the US FDA, for regulatory purposes, insisted that an investigational new drug application be filed before the success or failure of this approach could be determined.").

'See Subterranean Regulation, supra note 5, at 1259-62.

1- See id. at 1256, 1259-62 (discussing the "chilling effects" of the FDA's method of regulation on advanced assisted reproductive technologies including cytoplasmic transfer and mitochondrial donation). 
fell further behind in the race towards the clinical use of mitochondrial transfer as a number of safety and ethical issues overlap between cytoplasmic transfer and mitochondrial transfer. ${ }^{11}$ Instead, U.S.-based physicians and patients have been driven to reproductive tourism where they provide these techniques in countries with less restrictive regulation. ${ }^{12}$ Thus, those opposed to the type of work involving mitochondrial transfer have succeeded in halting the use of the technique in the United States, whereas institutional structures in the United Kingdom have thoroughly considered the ethical and legal issues surrounding the use of the technique before ultimately approving it. ${ }^{13}$

This article applies a comparative analysis to ART innovation before concluding that the United States should undertake a public consultation related to ART innovation similar to the United Kingdom. The political science subfield of comparative politics has often focused on the European Union's purported "democratic deficit," which some have blamed for the U.K.'s vote to leave the E.U. ${ }^{14}$ While there is no standard definition of the "democratic deficit," generally, when a national or supranational body suffers from a "democratic deficit," that body lacks public accountability, transparency, and public engagement. ${ }^{15}$ As explained infra, the United Kingdom's approach to this technique was to eventually legalize it after an extensive public consultation, whereas the United States' approach has been to use administrative law to hinder the use of this technology, and a preceding but similar technology, cytoplasmic transfer, without having any public discourse on the social, ethical, and political considerations implicated by the technique. ${ }^{16}$

This article contributes to the health law, family law, innovation law, and administrative law literatures. In health law and family law, there is a significant (and

\footnotetext{
${ }^{11}$ Id. at 1271-79.

${ }^{12}$ See sources cited infra note 117 and accompanying text discussing the work of Dr. John Zhang, a U.S.based physician, in Mexico; infra notes 195, 199 discussing reproductive and medical tourism.

${ }^{13}$ See infra Part III; see also Doctors Given Approval for LK's First 'Three-Person Babies', BBC NEWs (Feb. 2, 2018), https://www.bbc.com/news/health-42918341 [https://perma.cc/U92N-LTEE].

${ }^{14}$ See K.K. DuVivier. The Linited States as a Democratic Ideal? International Lessons in Referendum Democracy, 79 TEMP. L. REV. 821, 855 n. 245 (2006); R. Daniel Kelemen, Europe's Other Democratic Deficit: National Authoritarianism in Europe's Democratic Lnion, 52 Gov'T \& OPPOSITION 211, 211 ("For years, many scholars of European integration have argued that the EU suffers from a democratic deficit, due to the lack of public engagement and political accountability at the EU level and the absence of a common public sphere or common demos characteristic of national democracies."); id. at $211 \mathrm{n} . \mathrm{l}$; Stephen C. Sieberson, The Proposed European Lnion Constitution - Will it Eliminate the EL's Democratic Deficit?, 10 COLuM. J. EuR. L. 173, 174 (2004); id. at 195 ("Democratic deficit . . refers to the legitimacy problems of non-majoritarian institutions, i.e., institutions which by design are not directly accountable to the voters or to their elected representatives." (citing Giandomenico Majone, Europe's 'Democratic Deficit': The Question of Standards, 4 EUR. L.J. 5, 15 (1998)).

${ }^{15}$ See Andreas Follesdal \& Simon Hix, Why There is Democratic Deficit in the EL: A Response to Majone and Moravcsik, $44 \mathrm{~J}$. COMMON MKT. STUD. 533, 534 (2006) ("There is no single meaning of the 'democratic deficit'. Definitions are as varied as the nationality, intellectual positions and preferred solutions of the scholars or commentators who write on the subject. Making a similar observation in the mid-1990s, Joseph Weiler and his colleagues set out what they called a 'standard version' of the democratic deficit."); 534-36 (providing five elements of a "standard version" of the democratic deficit: "First, and foremost, European integration has meant an increase in executive power and a decrease in national parliamentary control... Second, and related to the first element, most analysts of the democratic deficit argue that the European Parliament is too weak. . . . Third, despite the growing power of the European Parliament, there are no 'European' elections. . . . Fourth, even if the European Parliament's power were increased and genuine European elections were able to be held, another problem is that the EU is simply 'too distant' from voters. .

Fifth, European integration produces 'policy drift' from voters' ideal policy preferences."); Peter L. Lindseth, Democratic Legitimacy and the Administrative Character of Supranationalism: The Example of the European Community, 99 COLUM. L. REV. 628, 657, 684 (1999).

${ }^{16}$ See Subterranean Regulation, supra note 5, at 1241-45; infra Part III; .
} 
often overlapping) literature addressing ART innovation and the consequences of using ART. ${ }^{17}$ The article simultaneously contributes to the health law and administrative law literatures by revealing how the operation of administrative law may be hindering innovation in medicine. ${ }^{18}$ More specifically, the article contributes a specific subset of the "health-care administrative law" literature surrounding ART and innovative therapies by using the concept of "democratic deficit," a political science concept, to illustrate a lack of transparency and public participation in the regulation of innovations in ART. ${ }^{19}$ Moreover, from the perspective of innovation and technology govemance, the divergent experiences of the United States and the United Kingdom on advanced assisted reproductive technologies indicates that, in the realm of advanced assisted reproductive technology, the general approach to risk where, "for example Europe tends to give greater prominence to precaution while the United States assigns a stronger role to liability" is reversed. ${ }^{20}$ Due to the role of administrative institutions in the analysis, the article also implicates comparative administrative law and comparative health law. ${ }^{21}$

${ }^{17}$ See Michele Goodwin, Prosecuting the Womb, 76 GEO. WASH. L. REV. 1657, 1693 (2008); Alexander N. Hecht, The Wild Wild West: In dequate Regulation of Assisted Reproductive Technology, 1 Hous. J. HEALTH L. \& POL'y 227, 228 (2001); see also NAOMIR. CAHN, TEST TUBE FAMILIES: WHY THE FERTILITY MARKET NEeds Legal Regulation vii, 1-10 (2009); Debora L. SPaR, THE Baby Business: How MONEy, SCIENCE, and Politics Drive the Conmerce of Conception 5 (2006); Courtney M. Cahill, The Oedipus Hex: Regulating Family After Marriage Equality, 49 U.C. DAVIS L. REV. 183 (2015); Naomi R. Chan \& Jennifer M. Collins, Eight is Enough, 103 Nw. U. L. COLlOQUY 501, 507 (2009); Judith F. Daar, Regulating Reproductive Technologies: Panace or Paper Tiger?, 34 Hous. L. REV. 609, 615 (1997) ("[Assisted reproductive technology] is subject to little formal regulation"); Marsha Garrison, Regulating Reproduction, 76 GEO. WASH. L. REV. 1623 (2008); Hank Greely, Cloning and Government Regulation, 53 HASTINGS L.J. 1085, 1089-90 (2002); Kathryn V. Lorio, The Process of Regulating Assisted Reproductive Technologies: What We Can Learn from Our Neighbors- What Translates and What Does Not, 45 LOY. L. REV. 247, 247 (1999); Kimberly M. Mutcherson, Blood and Water in a Post-Coital World, 49 FAM. L. Q. 117, 127 (2015); Lars Noah, Assisted Reproductive Technologies and the Pitfalls of Lnregulated Biomedical Innovation, 55 FlA. L. REV. 603, 614-15 (2003); Gaia Bernstein, Regulating Reproductive Technologies: Timing, Uncertainty, and Donor Anonymity, 90 B.U. L. REV. 1189, 1196-1205 (2010); June Carbone \& Paige Gottheim, Markets, Subsidies, Regulation, and Trust: Building Ethical Lnderstandings into the Market for Fertility Services, 9 J. GENDER RACE \& JUST. 509, 511 (2006) ("The regulation of fertility services involves the creation of norms about a new and rapidly growing technology.).

${ }^{18}$ See Timothy S. Jost, Health Law and Administrative Law: A Marriage Most Convenient, 49 ST. LOUIS U. L. J. 1, 14-16, 29 (2004); infra Part I.B.

${ }^{19}$ See, e.g., Daniel A. Farber \& Anne J. O'Connell, The Lost World of Administrative Law, 92 TEX. L. REV. 1137, 1137 (2014) (identifying administrative law's goals as "transparency, rule of law, and reasoned implementation of statutory mandates"); Emily Hammond \& David L. Markell, Administrative Proxies for Judicial Review: Building Legitimacy from the Inside-Out, 37 HARV. ENVTL. L. REV. 313, 316 (2013) (identifying "administrative law values of participation, deliberation, and transparency, which guard against arbitrariness and foster accountability"); Jost, supra note 18, at 1 (referring to the concept of "health-care administrative law"); id. at 9-14; Michael A. Livermore, Political Parties and Presidential Oversight, 67 ALA. L. REV. 45, 110 (2015); Robert Rohrschneider, The Democracy Deficit and Mass Support for an EL-Wide Government, 46 AM. J. OF POLI. SCI. 463, 463 (2002); Miriam Seifter, Second-Order Participation in Administrative Law, 63 UCLA L. REV. 1300, 1302 (2016) ("[P]ublic participation is a cornerstone of administrative law.")

20 Gary Marchant, Resilience: A New Tool in the Risk Governance Toolbox for Emerging Technologies, 51 U.C. DAVIS L. REV. 233, 245 (2017).

${ }^{21}$ See Francesca Bignami, From Expert Administration to Accountability Network: A New Paradigm for Comparative Administrative Law, 59 AM. J. COMP. L. 859, 860 (2011) ("Comparative administrative law... seeks to uncover the similarities and differences that mark multiple legal systems."); Susan Rose-Ackerman, Comparative Administrative Law: Outlining a Field of Study, 28 WINDSOR Y.B. ACCESS JUST. 435, 436 (2010). For more on comparative health law, see generally Diane Hoffmann, Comparative Health Law and Policy: What, If Anything, Can We Learn from Other Countries?, 37 J.L. MED. \& ETHICs 790 (2009). 
Ultimately, the lessons from this project may be useful for or extrapolated to other regimes. ${ }^{22}$

The article proceeds as follows. In part II, the article provides background information on ART and the concept of the democratic deficit. In part III, the article provides an overview of the regulatory systems governing innovation in and the use of ART in the United States and the United Kingdom, with an emphasis on the two countries' disparate regulatory approaches to traditional and newer forms of ART involving genetic modification. Part IV uses the comparative and domestic legal analyses from part III to explore the implications of the United States' approach to ART regulation on innovation in the United States, including the existence of a democratic deficit in ART innovation and use in the United States. Part V prescribes a potential process of public consultation for the U.S., based on the U.K.'s five-strand consultation on mitochondrial transfer, before concluding.

\section{SCIENTIFIC AND CONCEPTUAL BACKGROUND}

This part provides background in the areas of political science and ART. Section A describes the broader concept of ART, with an emphasis on IVF before describing "advanced assisted reproductive technologies" which are forms of ART involving genetic modification that are distinct from gene editing, another innovation that has received significant media attention lately. ${ }^{23}$ Section B offers an overview of the concept of "democratic deficit."

\section{A. Assisted ReProductive TeCHNOLOGy}

The term "ART" can have many definitions depending on the purposes for which the term is being used. ART is a broad field that "usually involves in vitro

\footnotetext{
${ }^{22}$ See Sandy Ong, Singapore Could Become the Second Country to Legalize Mitochondrial Replacement Therapy, SCIENCE (Jun. 6, 2018), http://www. sciencemag.org/news/2018/06/singapore-could-becomesecond-country-legalize-mitochondrial-replacement-therapy [https://perma.cc/BTY2-PMSX]; Scientists Say it's Time to Make '3-Parent Baby' Technology Legal in Canada, CBC RADIO (Mar. 26, 2018), https://www.cbc.ca/radio/quirks/march-24-2018-an-alien-looking-skeleton-three-parent-families-in-canadaand-more-1 .4588650/scientists-say-it-s-time-to-make-3-parent-baby-technology-legal-in-canada-1 4588671 [https://perma.cc/ZN5R-SZ4C] (providing comment of Health Canada on possible legal changes to accommodate new forms of assisted reproductive technology, "Health Canada is the federal authority responsible for administering and enforcing the Assisted Human Reproduction (AHR) Act. The AHR Act prohibits a person from knowingly altering the genome of a cell of a human being or in vitro embryo such that the alteration is capable of being transmitted to descendants. Genome is defined in the AHR Act as the totality of the deoxyribonucleic acid (DNA) sequence of a particular cell. Since mitochondrial replacement therapy involves the introduction of mitochondrial DNA from a third party and since the introduced DNA is capable of being inherited by the resulting embryo, a person performing this procedure in Canada would be violating a provision of the AHR Act. ... After the current regulatory project is complete, the Department will consider the need to amend the Assisted Human Reproduction (AHR) Act to reflect advances in science that have taken place since the Act was first enacted in 2004. This will include revisiting the prohibition in the Act that currently makes it illegal in Canada for a person to conduct mitochondrial replacement therapy (MRT). Health Canada recognizes the promise that the application of this technology, and other technologies that create heritable changes to the genome, may hold. However, further consideration is required, including whether changes to the prohibitions would continue to reflect the values of Canadians, before such changes could be contemplated.").

${ }^{23}$ See Subterranean Regulation, supra note 5, at 1241. This Article focuses on forms of assisted reproductive technology involving genetic modification such as mitochondrial transfer and cytoplasmic transfer, although as will be explained in Parts III and IV, the lessons from this Article, which addresses medical techniques that are accompanied by ethical controversy, could eventually be relevant in similar studies of gene editing technologies. This Article focuses on assisted reproductive technology involving heritable genetic modifications, and while there are some aspects of it that are similar to gene editing (and many that are not), comparative aspects of the regulation of gene editing will be the focus of a subsequent Article.
} 
fertilization," where "an egg is removed from [a] woman's ovary and fertilized with [a] man's sperm in a petri dish" in a laboratory setting. ${ }^{24}$ "If fertilization occurs, the resulting embryo is" implanted into a woman's uterus. ${ }^{25}$ In the United States, the Centers for Disease Control and Prevention ("CDC"), which is part of the U.S. Department of Health and Human Services ("HHS"), explains the term as

"...includ[ing] all fertility treatments in which both eggs and embryos are handled. In general, ART procedures involve surgically removing eggs from a woman's ovaries, combining them with sperm in the laboratory, and returning them to the woman's body or donating them to another woman. They do NOT include treatments in which only sperm are handled (i.e., intrauterine-or artificial-insemination) or procedures in which a woman takes medicine only to stimulate egg production without the intention of having eggs retrieved." 26

The CDC's definition of ART draws on the only federal statute that is clearly applicable to ART, the 1992 Fertility Clinic Success Rate Act. ${ }^{27}$ Other operating divisions of the HHS use similardefinitions, as do the National Academies of Science, Engineering, and Medicine, Society for Assisted Reproductive Technology, and American College of Obstetricians and Gynecologists. ${ }^{28}$ In the United Kingdom, the Human Fertilisation and Embryology Authority, National Health Service, and the UK's National Institute for Health and Care Excellence use similar definitions of ART (also referred to as "assisted conception") and "fertility treatment," as the CDC. ${ }^{29}$

${ }^{24}$ Lori B. Andrews \& Lisa Douglass, Alternative Reproduction, 65 S. CAL. L. REV. 623, 631 (1991); see Frequently Asked Questions: Gynecologic Problems, Am. COLlege OF OBSTETRICIANS \& Gynecologists (Oct. 2017), https://www.acog.org/Patients/FAQs/Treating-Infertility? IsMobileSet=false\#assisted [https://perma.cc/V9ZY-R8XC]. For an overview of the mechanics of in vitro fertilization, see John A. Robertson, Embryos, Families, and Procreative Liberty: The Legal Structure of the New Reproduction, 59 S. CAL. L. REV. 939, 944-52 (1986).

${ }^{25}$ Andrews \& Douglass, supra note 24, at 631; see Lars Noah, Assisted Reproductive Technologies and the Pitfalls of Linregulated Biomedical Innovation, 55 FLA. L. REV. 603, 608 (2003) (characterizing in vitro fertilization as "represent[ing] the paradigmatic form of ART").

${ }^{26}$ What is Assisted Reproductive Technology? CTRS. FOR DISEASE CONTROL \& PREVENTION (Feb. 7, 2017), https://www.cdc.gov/art/whatis.html [https://perma.cc/Q5B7-W25L].

${ }^{27}$ Id.; see 42 U.S.C. \$\$ 201, 263a-1-a-7 (2012); Yaniv Heled, The Regulation of Genetic Aspects of Donated Reproductive Tissue - The Need for Federal Regulation, 11 COLUMBIA SCI. \& TECH. L. REV. 243, 250-51 (discussing the Fertility Clinic Success Rate Act of 1992); Jamie King, Predicting Probability: Regulating the Future of Preimplantation Genetic Screening, 2 YALE J. HEALTH LAW, POL'Y, \& ETHICS 101, 153 (2008) (noting that "[o]verall, the $\mathrm{CDC}$ has very limited power over ART clinics. [The Fertility Clinic Success Rate Act] specifically states that the "Secretary [of the Department of Health and Human Services] may not establish any regulation, standard or requirement which has the effect of exercising supervision or control over the practice of medicine in ART programs.").

${ }^{28}$ See Nat'l Research Council, Scientific and Medical Aspects of Human Reproductive Cloning 61 (2002); Assisted Reproductive Technology, NAT'L CANCER Instit. Dictionary OF GENETICS Terms, https://www.cancer.gov/publications/dictionaries/genetics-dictionary/def/assisted-reproductive-technology [https://perma.cc/GA6B-9N3L] ("A term used to describe collectively a number of noncoital methods of conception that are used to treat infertility with donor or nondonor eggs and sperm including in vitro fertilization (IVF), gamete intrafallopian transfer (GIFT), and zygote intrafallopian transfer (ZIFT). Also called ART."); Assisted Reproductive Technologies, SOC'Y FOR AsSISTED REPRODUCTIVE TECH., https://www.sart.org/topics/topics-index/assisted-reproductive-technologies/ [https://perma.cc/SFT2-V8SC]. 29 NAT'L Health Serv., CliniCal Commissioning Policy: Assisted ConCEPTIOn, ReFERENCE, 2014, : NSC/037, at 5-7, 9, https://www.england.nhs.uk/commissioning/wp-content/uploads/sites/12/2014/11/nsc037.pdf ("Assisted reproduction [:] The collective name for treatments designed to lead to conception by means other than sexual intercourse. Assisted reproduction techniques include intrauterine insemination (IUI), 
Two techniques of ART, cytoplasmic transfer and mitochondrial transfer, combine IVF with genetic modification by combining or substituting, respectively, the genetic material of the sperm and eggs that would usually be used in IVF, with the genetic material from the mitochondria or cytoplasm of a donor egg. ${ }^{30}$ Mitochondrial transfer, or mitochondrial donation, is a form of ART that aims to prevent the transmission of mitochondrial disease from parent to child ${ }^{31}$ There are two techniques that are encompassed by the term "mitochondrial transfer": pronuclear transfer ("PNT") and matemal spindle transfer ("MST"). ${ }^{32}$ These two techniques are the most commonly analyzed in contemporary media coverage of mitochondrial transfer and reports related to approval of the techniques. ${ }^{33}$ Cytoplasmic transfer is a form of ART that has received less media attention lately but was a "precursor" to mitochondrial transfer. ${ }^{34}$ Cytoplasmic transfer involves IVF, where the egg of the intended mother would be "revitalized" by the cytoplasm of a donor egg, in a technique that improved fertility outcomes in the 1990s and early 2000s ${ }^{35}$ As will be detailed infra in Part II, both cytoplasmic transfer and mitochondrial transfer have been subject to FDA responses that have had "chilling effects" on research and clinical practice.

Other than the Fertility Clinic Success Rate Act, professional organizations, such as the American College of Obstetricians and Gynecologists and Society for Assisted Reproductive Technology, play an important role in the regulation of

\footnotetext{
in vitro fertilisation (IVF), intracytoplasmic sperm injection (ICSI) and donor insemination (DI). The term 'assisted reproduction technology' (ART) is the term sometimes used to collectively describe these procedures and interventions."); Explore Fertility Treatments, HumAN FERTILISATION \& EMBRYOLOGY AUTH. (Nov. 9, 2018), https://www.hfea.gov.uk/treatments/explore-all-treatments [https://perma.cc/KH8M-DN36] (describing intrauterine insemination (IUI), in vitro fertilization, Intracytoplasmic sperm injection (ICSI), fertility drugs, IVF options, surgical sperm extraction, surgery, and surrogacy); Fertility Problems: Assessment and Treatment, Clinical Guideline [CG156], NAT'L INST. FOR HEALTH \& CARE EXCELlENCE (Feb. 2013), https://www.nice.org.uk/guidance/cgl56/ifp/chapter/assisted-reproduction [https://perma.cc/6CFD-4CYX] ("Assisted reproduction [:] Assisted reproduction is the name given to treatments that can help you get pregnant without you having sexual intercourse. There are a variety of treatments, and what is suitable for you will depend on your own circumstances. The options include: intrauterine insemination (IUI)[;] in vitro fertilisation (IVF)[;] IVF with intracytoplasmic sperm injection (ICSI)[;] the use of donor sperm (donor insemination) or eggs (egg donation). ... Other methods of assisted reproduction called gamete intrafallopian transfer (GIFT) or zygote intrafallopian transfer (ZIFT) are not recommended. Certain forms of assisted reproduction (IUI, IVF, ICSI, donor insemination and egg donation) are regulated by law and their use is controlled by the Human Fertilisation and Embryology Authority"); How We Regulate, HumAN FERTILISATION \& EMBRYOLOGY AUTH., https://www.hfea.gov.uk/about-us/how-we-regulate/ [https://perma.cc/TF4S-E8BZ].

30 See Subterranean Regulation supra note 5, at 1248-49 "'A cell essentially contains three parts: cytoplasm, nucleus, and mitochondria. The nucleus, which is the center of the cell, is

surrounded by cytoplasm. Mitochondria are located in the cytoplasm of the cell." (citations omitted)); see also Paula Amato et al., Three-Parent II F: Gene Replacement for the Prevention of Inherited Mitochondrial Diseases, 101 FERTIL. STERIL. 31, 32-34 (2014).

${ }^{31}$ For more explanation of how the various techniques of mitochondrial transfer operate, see A.S. Reznichenko et al., Mitochondrial Transfer: Implications for Assisted Reproductive Technologies, 11 APPLIED \& TRANSlational GENOMICS 40, $41-44$ (2016); Tian Wang et al., Polar Body Genome Transfer for Preventing the Transmission of Inherited Mitochondrial Diseases, 157 CELL 1591, 1591 (2014); Wolf et al., supra note 8 , at 69-71.

32 See NuFFIELd COUNCIL ON BIOETHICS, NOVEL TECHNIQUES FOR THE PREVENTION OF MITOCHONDRIAL DNA DISORDERS: AN ETHICAL REVIEW vii, 36 (2014) ("The main difference between [maternal spindle transfer and pronuclear transfer] is that MST uses two unfertilized eggs to reconstruct an egg with healthy mitochondria that can be fertilized; in PNT, two early embryos (zygotes) are used to reconstruct an embryo with healthy mitochondria."); Mitochondrial Donation Treatment, supra note 6.

${ }^{33}$ See NufFIELD COUNCIL ON BIOETHICS, supra note 32 , at 34.

${ }^{34}$ Subterranean Regulation, supra note 5, at 1248-50.

${ }^{35}$ Id.
} 
reproductive technology by serving as "self-regulatory" or "peer regulatory" organizations for physicians involved in the practice of ART. ${ }^{36}$ ART is highly regulated in the United Kingdom, as detailed in part III.A.1, but is minimally regulated in the United States, with the exception of forms of ART involving genetic modifications (referred to herein as "advanced assisted reproductive technologies"), which are highly regulated, as detailed in part III.B.1.

In 2005, the UK's Human Fertilisation and Embryology Authority granted a license to researchers at Newcastle University to conduct mitochondrial research. ${ }^{37}$ In April 2010, a group of scientists at Newcastle University published a paper in the joumal Nature, providing "proof of concept" of pronuclear transfer. ${ }^{38}$ In 2009, researchers at Oregon Health and Science University announced that they had successfully used maternal spindle transfer in rhesus macaques. ${ }^{39}$ However, as is detailed in part III of the article, because the Oregon Health and Science University researchers were located in the United States, their work has been stymied by the machinations of the administrative state and Congressional funding restrictions. As will be emphasized in part IV of the article, there is a lack of public participation and transparency in those machinations of the administrative state, even though there are indications that those machinations involve the use of political or social considerations by FDA employees, without a

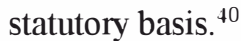

\section{B. DEMOCRATIC DEFICIT}

The term "democratic deficit" was first used in 1977 and has since occupied a significant space in the political science literature. ${ }^{41}$ Although there is no standard definition of "democratic deficit," the concept of the "democratic deficit" highlights a failure to achieve many of the goals of the American democratic state such as legitimacy,

\footnotetext{
36 See Robertson, supra note 24, at 1035-36 ("With adequate peer involvement, more explicit legal controls, such as the national licensing authority suggested in the Warnock Report, need not take root in American soil."); Jennifer L. Rosato, The Children of Art (Assisted Reproductive Technology): Should the Law Protect Them from Harm?, 2004 UTAH L. REV. 57, 66 (2004) ("The American Society for Reproductive Medicine ('ASRM') is the primary professional organization that oversees the field of reproductive medicine, and the Society of Assisted Reproductive Technology ('SART'), an affiliated organization, specifically covers IVF programs, in addition to other types of ART programs."(citations omitted)). The Institute of Medicine's recommendation on the eventual use of mitochondrial transfer in the United States were directed at both the FDA and "professional societies." See THE NAT'L ACADS. OF SCI., EnG'G. \& MED., MitochOndRIAL Replacement TeChniques: Ethical, Social, and Policy Considerations 7, 71, 99 (2016) ("The committee does not suggest an absolute limit on any eventual applicability of MRT to other conditions or diseases, but rather believes FDA and relevant professional societies need to take cautious approach, with deliberate attention to ethical, social, and policy issues, in considering any uses of MRT beyond the primary indication of preventing transmission of serious mtDNA disease." (emphasis added)).

${ }^{37}$ See NufFIELd COUNCIL ON BIOETHICS, supra note 32, at 34.

${ }^{38}$ See id.

${ }^{39}$ See id. at 36; see also Sabrina Tavemies, His Fertility Advance Draws Ire, N.Y. TIMES (Mar. 18, 2014).

${ }^{40}$ See, e.g., Nina Mendelson, Disclosing "Political" Oversight of Agency Decision Making, 108 MiCH L. REv. 1127, 1130-31 (2010); Subterranean Regulation, supra note 5, at 1271-74.

${ }^{41}$ See Sanford Levinson, How the Lnited States Constitution Contributes to the Democratic Deficit in America, 55 DRAKE L. REV. 859, 860 (2007); Martin Nettesheim, Developing Theory of Democracy for the European Union, 23 BERKELY J. INT'L L. 358, 358-59 n.l (2005); see also Daniel T. Deacon, Administrative Forbearance, 125 YALE L.J. 1548, 1589 (2016) ("One persistent criticism of the administrative state, and particularly of broad delegations, is that policy is frequently formulated through allegedly less transparent means. Less visible policymaking may lead to less accountable government." (citations omitted)).
} 
transparency, and an "equilibrium" between democracy and effectiveness. ${ }^{42}$ I use the term "democratic deficit" in this article to highlight the non-existence of those goals in the regulation of ART at the federal level, which occurs through the use of administrative law tools that do not involve notice-and-comment rulemaking or public participation.

While not all political scientists ascribe to the concept of "democratic deficit" in the European Union, many analyses of the European Union and the United States have examined political and legal challenges through the lens of the democratic deficit. ${ }^{43}$ The term "democratic deficit[]" "... first arose in debates about the legitimacy of the European Union ("EU"), and has continued to surface in debates about the legitimacy of the European Union and the analysis of actors in the European Union." ${ }^{44}$ Most recently, the Brexit vote has been analyzed as a response to the "democratic deficit" in the European Union. ${ }^{45}$

As a matter of brief historical context, the European Union is characterized as suffering from a "democratic deficit" due to its institutional structures: the Ministers of the Council of the European Union are "... a collectivity of nonelected civil servants" with the authority to pass binding, enforceable legislation, without the approval of the European Parliament, a legislative body that has been characterized as "weak." 46

\footnotetext{
${ }^{42}$ See Jan Rovny, Approaches to the Democratic Deficit in the Europen Lnion, 19 PERSPECTIVES: REV. OF CENTRAL EUR. AFFAIRS 109, 110, 113 (2003); see also sources cited supra note 19 and accompanying text (identifying the goals of the American administrative state).

${ }^{43}$ See PipPa NorRis, Democratic Deficit: Critical Citizens Revisited 3, 5 (2011) ("The gap between aspirations and satisfaction is captured here by the concept of democratic deficits. The notion first arose in debates about the legitimacy of the European Union (EU). The core decision-making institutions in the EU have been regarded by some commentators as falling well short of the standards of democratic accountability and transparency that exist at the national level within each of the member states."); Levinson, supra note $4 \mathrm{i}$, at 861-62 ("There is in fact an interesting debate going on about the extent of the democratic deficit in Europe"); id. at 862-64 (discussing the democratic deficit in the context of election law and American federal and state constitutional law); id. at 862 n.4; Ernest A. Young, Protecting Member State Autonomy in the European Lnion: Some Cautionary Tales from American Federalism, 77 N.Y.U. L. REV. 1612, 1639 (2002) [hereinafter Protecting Member State Autonomy]; Maimon Schwarzschild, Complicated-But Not Too Complicated: The Sunset of E. U. Law in the U.K. After Brexit, 39 CARDOZOL. REV. 905, 905 n.2 (2018); see also James Allan, Democracy, Liberalism, and Brexit, 39 CARDOZO L. REV. 879, 887-94 (2018) (discussing "democratic deficiencies" in the context of the European Union); Ernest A. Young, What Can Europe Tell Lis About the Future of American Federalism?, 49 ARIZ. ST. L.J. 1 109, 1136 (2017) [hereinafter Future of American Federalism]; Peter Millar, What's all this about the EL's 'Democratic Deficit'?, THE GUARDIAN (May 20, 2013), https://www.theguardian.com/commentisfree/2013/may/20/eu-democratic-deficit. [https://perma.cc/QXF7-PVXF].

${ }^{44}$ See NORRIS, supra note 43, at 5; see also Andrew Moravcsik, Is There a 'Democratic Deficit' in World Politics? A Framework for Analysis, 39 GOV'T AND OPPOSITION 336, 337 (2004) (noting that the European Union "is widely considered to suffer from a 'democratic deficit', the redressing of which was the primary purpose for calling the ongoing constitutional convention and negotiation."). For more on the democratic deficit in the European Union, see J.H.H. Weiler, The Transformation of Europe, 100 YALE L.J. 2403, 2430, 2466-7, 2469 (1991).

${ }^{45}$ See Harold D. Clarke ET AL., BreXit 72, 114 (2017); Matthew Goodwin et al., For and Against Brexit: A Survey Experiment of the Impact of Campaign Effects on Public Attitudes toward EL Membership, BRITISH JouRnAl OF POlitiCAL SCIENCE, at 1, 5 (2018); Samuel Issacharoff, Democracy's Deficits, 85 U. CHI. L. ReV. 485, 493-94 (2018) ("In this sense, the desperate gambit of Prime Minister David Cameron [in using the referendum on the UK's membership in the EU] ... well follows the pattern in the European Union of seeking to alter its perceived democratic deficit through greater use of referenda and other tools of direct democracy." (citations omitted)); Timothy G. Ash, As an English European, This is the Biggest Defeat of my Political Life, THE GuARDIAN (Jun. 24, 2016) (discussing "Euroskepticism").

${ }^{46}$ Weiler, supra note 44, at 2465-68 (1991); see Overview, COUNCIL OF THE EUROPEAN UNION (Feb. 19, 2019), https://europa.eu/european-union/about-eu/institutions-bodies/council-eu en [https://perma.cc/34ATRF89]. While there are significant literatures in political science, comparative law, and administrative law that analyze the European Union, this Article only analyzes the European Union in order to illustrate the concept
} 
Through structures that lack accountability, transparency, and legitimacy, such as the Council of the European Union, which

exercise[s legislative power] 'behind closed doors'... 'and, at a lower level, by numerous committees of national experts, who are faceless and unaccountable,' [through] a process [which is] 'hardly consistent with the rules of democracy, even in the eyes of those who understand that in the formation of legislative proposals there is limited scope for transparency. ${ }^{47}$

While the "democratic deficit" is a political science term that is generally applied to analyses of the European Union, it is relevant to legal analysis, especially as it relates to U.S. administrative law. ${ }^{48}$ In the legal literature, the term has been used to explore broader concerns in U.S. law, often from a comparative perspective in which scholars explore various issues related to the Constitution of the United States and state constitutions. ${ }^{49} \mathrm{~A}$ lack of these democratic features leads to a democratic deficit similar to the one that scholars attribute to the European Union's method of governance through structures like the Council of the European Union. ${ }^{50}$ Further, methods of avoiding democratic deficit include increasing the representation of the public in the political system, which the American administrative state aims to do through methods of public participation like notice-and-comment rulemaking. ${ }^{51}$ Nonetheless, many aspects of federal administrative decision-making related to advanced assisted reproductive technologies do not include public participation, as will be emphasized in part III..$^{52}$

This article uses the political science concept of the "democratic deficit" to address the lack of American public discourse on the subjects of ART and more recently, advanced assisted reproductive technologies which involve genetic modifications in combination ART. While America's "democratic deficit" in the realm of ART does not have the same political consequences as the E.U.'s democratic deficit, there is no supranational body that can impose binding legislation on the American federal govemment without its approval, a democratic deficit still exists within the administrative state. Even though the appointment of the FDA Commissioner involves

of the democratic deficit, which the Article then uses to examine the regulation of assisted reproductive technology in the United States and United Kingdom.

${ }^{47}$ Rovny, supra note 42, at 110,113; Sieberson, supra note 14 , at 195.

${ }^{48}$ See Curtis A. Bradley, International Delegations, the Structural Constitution, and Non-Self-Execution, 55 STAN. L. REV. 1557, 1558 n. 3 (2003); Levinson, supra note 41, at 860 ("The term 'democratic deficit' has become a staple in contemporary political analysis.").

${ }^{49}$ See Future of American Federalism, supra note 43, at 1112 ("Finally, the Brexit vote and the parallel rise of Euroskeptic movements in France and other Member States reflects profound popular concerns about the legitimacy of governance at the center. Although the United States has not generally been thought to suffer from the same sort of "democratic deficit" that haunts European discourse, we are experiencing profound frustration with gridlocked and nonresponsive government in Washington, reflected in the precipitous decline in public trust in national goveming institutions. We are unlikely to see a 'Texit' (or perhaps more likely, a 'Utexit' or 'West Virgexit') but it is nonetheless time to ask how the eroding legitimacy of national government may affect American federalism."(citations omitted)); Dragoljub Popovic, Prevailing of Judicial Activism Over Self-Restraint in the Jurisprudence of the European Court of Human Rights, 42 CREIGHTON L. REV. 361, 364 (2009) (discussing the democratic deficit in the context of unelected judges in the American judiciary).

See sources cited supra note 43 (discussing the democratic deficit in the European Union with an emphasis on the Council of the European Union).

${ }^{51}$ Rovny, supra note 42, at 112; see Kristin Hickman, Lnpacking the Force of Law, 66 VANDERBLT L. REV. 465, 520 (2013).

${ }^{52}$ See infra Part III.B.1. 
both the Executive and Legislative Branches, which are both democratically accountable to the public, the democratic deficit where "... a collectivity of nonelected civil servants" can incorporate social and political views into administrative agency decisions that are not subject to public input still has significant legal and practical consequences in the realms of access to ART due to the binding nature of many administrative agency decisions as will be highlighted in part III. ${ }^{53}$ Examining the FDA regulation of ART through the lens of the democratic deficit highlights how, in the context of FDA regulation of ART, the administrative state has operated to hinder the use of advanced assisted reproductive technologies. ${ }^{54}$

\section{REGULATORY BACKGROUND}

This article uses a comparative legal (and political) analysis to explore the differences in the regulation of forms of ART involving genetic modification in the United States and the United Kingdom. ${ }^{55}$ The selected case studies are countries that have the technology to implement widespread use of mitochondrial transfer, but have diverged in terms of the clinical use and governance of the technology ${ }^{56}$ Not only are the United States and the United Kingdom two countries where the most scientific progress in mitochondrial transfer has occurred, the countries' governments share some historical and democratic commonalities..$^{57}$

\footnotetext{
${ }^{53}$ Weiler, supra note 44, at 2465-68; see James T. O'Reilly, Losing Deference in the FDA 's Second Century: Judicial Review, Politics, and Diminished Legacy of Expertise, 93 CORNELL L.REV. 939, 959-60 (2008) (describing the appointment processes for the Secretary of Health and Human Services (appointed by the President to his Cabinet) and the FDA Commissioner and other political appointees at the FDA (who are appointed by the President and confimed by the Senate).

${ }^{54}$ For more on the "democratic deficit" in the context of the United Kingdom and the United States, see Future of American Federalism, supra note 43, at 1112.

${ }^{55}$ See Kathryn V. Lorio, The Process of Regulating Assisted Reproductive Technologies: What We Can Learn from Our Neighbors - What Translates and What Does Not, 45 LOY. L. REV. 247, 248-49 (1999) ("Although no one system, or any combination of systems, may be ideal for the United States to emulate, both understanding and insight may be gained from a comparative analysis.").

56 While media reports have noted that scientists in China is making headway in the field of mitochondrial transfer, this Article does not focus on the experience of China as it would be difficult to draw lessons from the Chinese experience since the country is known for having a lack of regulation in the area of scientific research. Nevertheless, China's Academy of Sciences has been involved in multiple international germline editing summits. This Article does not explore the issue of whether mitochondrial transfer is "germline editing." For more on the definition of the germline, see Subterranean Regulation, supra note 5, at 1249-50, 1276-78 (2018). For more on CRISPR-Cas9 gene editing in China, see Dennis Normile, CRISPR Bombshell: Chinese Researcher Claims to Have Created Gene-Edited Twins, SCENCE (Nov. 26, 2018), https://www.sciencemag. org/news/2018/11/crispr-bombshell-chinese-researcher-claims-have-created-geneedited-twins [https://perma.cc/8RLP-GACW]; Sarah Zhang, Chinese Scientists are Outraged by Reports of Gene-Edited Babies, Science, THE ATLANTIC (Nov. 27, 2018), https://www. theatlantic.com/science/archive/2018/1 1/china-crispr-babies/576784/ [https://perma.cc/RT2J 62TJ] ("China has spent billions tuming itself into a scientific powerhouse, but it still struggles with the perception that its scientists do not take ethics seriously. In 2015, when Chinese scientists raced ahead to use CRISPR to edit genes in human embryos, an international outcry ensued.").

${ }^{57}$ There are of course many similarities and differences between the United States and the United Kingdom, which have been (and continue to be) studied by scholars of comparative law, institutional design, and federalism. This Article only focuses on these similarities and differences as pertinent to the regulation of assisted reproductive technology by the United States and United Kingdom. For background, see Steven G. Calabresi, Does Institutional Design Make A Difference?, 109 Nw. U. L. REV. 577,578 (2015) (characterizing the United Kingdom as an "otherwise stable western constitutional democrac[y]"); but see id. at 582-83 ("In important respects, the U.S. federal government is far more powerful than the federal governments of the European Union, Argentina, Brazil, Germany, India, Mexico, Canada, Australia, South Africa, and, since devolution, the United Kingdom."); see also Martin Laffin \& Alys Thomas, The Lnited Kingdom: Federalism in Denial?, 29 PUBLIUS 89, 90-92, 106 (1999); Peter H. Schuck, Federalism, 38 CASE W. RES. J. INT'L L. 5,
} 
For the purposes of comparing the regulation of ART in the United States and the United Kingdom, it is useful to note that lawmaking in the United Kingdom is also very similar to that in the United States, although some of the terminology differs. ${ }^{58} \mathrm{Just}$ like in the United States, proposed legislation in the United Kingdom is called a "bill" and final legislation in the United Kingdom is an "Act." ${ }^{59}$ A statutory instrument is a "type of delegated legislation," ${ }^{60}$ which is similar to a regulation in the United States where statutory instruments provide clarity on the meaning of various statutory terms. ${ }^{61}$ Statutory instruments are normally drafted by the legal office of the relevant government department, which is why the draft regulations related to mitochondrial transfer were created by the UK Department of Health. ${ }^{62}$ Thus, in the realm of administrative law, the draft regulations permitting mitochondrial transfer became a "statutory instrument" after they were approved by Parliament. ${ }^{63}$ In the United States, relevant regulations related to mitochondrial transfer and other forms of ART are drafted by the FDA without any sort of legislative approval. ${ }^{64}$ This part provides background on the legal responses to various innovations in ART in the United Kingdom and the United States.

\footnotetext{
5-6 (2006); See also Erin Ryan, Secession and Federalism in the Lnited States: Tools for Managing Regional Conflict in A Pluralist Society, 96 OR. L. REV. 123, 164 (2017) ()(discussing the United States' "symmetrical federalism" and the United Kingdom's "asymmetrical federalism");

${ }^{58}$ As noted in the preceding footnote, there are of course many differences between lawmaking in the United States and United Kingdom; however, this paragraph (and the Article as a whole) focuses on detailing the aspects of lawmaking in the United States and the United Kingdom that are critical to understanding the regulation of assisted reproductive technology in both countries. Proposed legislation in the United Kingdom is called a "bill", and an Act is the term applied to a bill that has obtained a majority vote in both the House of Commons and House of Lords and "formal[] agree[ment] by the reigning monarch (known as Royal Assent)." See Bills and Legislation, U.K. PARLIAMENT, http://www.parliament.uh/business/bills-and-legislation/ [https://perma.cc/A4HJ-72VJ]; House of Commons, U.K. PARLIAMENT, http://www.parliament.uk/business/commons/ [https://perma.cc/HW6A-JUS9] ("[t]he UK public elects 650 Members of Parliament (MPs) to represent their interests and concerns in the House of Commons."); Members and Their Roles, U.K. PARLIAMENT, http://www.parliament.uhbusiness/lords/whos-in-the-house-oflords/members-and-their-roles/ [https://perma.cc/UHS8-47VP] ("Members of the House of Lords are appointed by the Queen on the advice of the Prime Minister"); see also Stephen Gardbaum, Political Parties, I'oting Systems, and the Separation of Powers, 65 AM. J. COMP. L. 229, 230 (2017) ("When the same party wins both the White House and Congress, the United States has 'unified' government resembling parliamentary systems, notwithstanding the formal separation of the two branches. Only during periods of 'divided' government, where different parties control the two branches, does the Framers' conception of institutional checks and balances--of ambition checking ambition--come close to reflecting the reality of American politics.").

${ }^{59}$ See sources cited supra note 58 and accompanying text.

"What is Secondary Legislation?, U.K. PARLIAMENT, http://www.parliament.uk/about/how/laws/delegated/ [https://perma.cc/MS69-VFP2].

${ }^{61}$ Because Acts of Parliament are often broad, "[statutory instruments] are used to provide the necessary detail that would be too complex to include in the Act itself." HOUSE OF COMMONS INFORMATION OFFICE, STATUTORY INSTRUMENTS 2 (2008), https://www.parliament.uk/documents/commons-informationoffice/107.pdf.

62 What is Secondary Legislation?, supra note 60; see Commons Debate Statutory Instrument on Mitochondrial Donation, U.K. PARLIAMENT (Feb. 3, 2015), http://www.parliament.uk/business/news/2015/february/commons-debate-statutory-instrument-onmitochondrial-donation/ [https://perma.cc/53QC-RXS5]; see Draft Regulations on 'Three Parent' II F Published, NAT'L HEALTH SERV. (Feb. 28, 2014), http://www.nhs.uk/news/2014/02February/Pages/Draftregulations-on-three-parent-IVF-published.aspx [https://perma.cc/3DMS-A78E].

${ }^{6}$ See Commons Debate Statutory Instrument on Mitochondrial Donation, supra note 62; The Human Fertilisation and Embryology (Mitochondrial Donation) Regulations 2015, 2015 No. 572, THE NAT'L ARCHIVES (Mar. 4, 2015), http://www.legislation.gov.uk/ukdsi/2015/9780111125816/contents [https://perma.cc/GS5L-HUYD].

${ }^{64}$ See Peter B. Hutt ET AL., FoOd and Drug Law: CaSeS And Materials 1154 (4th ed. 2014).
} 


\section{A. UNITED KINGDOM}

The United Kingdom is a prominent country in terms of ART innovation. The work of Robert Edwards and Patrick Steptoe led to the birth of the world's first baby as a result of IVF, Louise Brown, in the United Kingdom in 1978 ${ }^{65}$ In July 1982, the "Committee of Inquiry into Human Fertilisation and Embryology" was created. ${ }^{66}$ The committee's report, "the Warnock Report, ${ }^{67}$ made 64 recommendations, ${ }^{68}$ including that IVF continue to be available through the National Health Service, ${ }^{69}$ that children conceived through IVF have the right to basic donor information including the donor's genetic health," ${ }^{70}$ that written consent from couples using IVF be obtained ${ }^{71}$ that semen donors not have parental rights, ${ }^{72}$ and that various constraints apply to research involving human embryos. ${ }^{73}$ These recommendations eventually led to the creation of the UK's Human Fertilisation \& Embryology Authority and were incorporated into the United Kingdom's regulatory framework governing the use of ART and research related to innovation in ART. ${ }^{74}$

1. The United Kingdom's Regulatory Framework Governing Assisted Reproductive Technology Use and Innovation

${ }^{65}$ The Nobel Assembly at Karolinska Institutet, supra note 1.

“6 DeP'T OF HEALTH \& SOC. SEC., REPORT OF THE COMMITTEE OF INQUIRY INTO HIJMAN FERTILISATION AND EMBRYOLOGY (1984), https://www.hfea.gov.uk/media/2608/warnock-report-of-the-committee-of-inquiryinto-human-fertilisation-and-embryology-1984.pdf [hereinafter WARNOCK REPORT].

${ }^{67}$ See WARNOCK REPORT, supra note 66. For a chapter-by-chapter summary of the Warnock Report, see Jonathon J. LaTourelle, The Report of the Committee of Inquiry into Human Fertilisation and Embryology (1984), by Mary Warnock and the Committee of Inquiry into Human Fertilisation and Embryology, EMBRYO PROJECT ENCYCLOPEDIA (Oct. 2, 2014), https://embryo.asu.edu/pages/report-committee-inquiry-humanfertilisation-and-embryology-1984-mary-warnock-and-committee [https://perma.cc/BV6K-V7BN]. ).

${ }^{68}$ WARNOCK REPORT, supr note 66, at 80-86 (providing a "List of Recommendations" related to the clinical use of assisted reproductive technology and research on embryos).

"Id. at 32. In the United Kingdom, health care is provided by the National Health Service, which was created in 1948. See Robert H. Blank, The Lnited Kingdom: Regulation Through a National Licensing Authority, in COMPARATIVE BIOMEDICAL POLICY: GOVERNING Assisted REPRODUCTIVE TECHNOLOGIES 121 (2004). The National Health Service provides free health care for UK residents. See About the NHS, NAT'L HEAL TH SERV., (Apr. 13, 2016), http://www.nhs.uk/NHSEngland/thenhs/about/Pages/overview.aspx [https://perma.cc/S3FB LD8E].

70 WARNOCK REPORT, supra note 66 , at 24-25.

${ }^{71} I d$. at 25 .

${ }^{72} I d$.

${ }^{73}$ See Mary Warnock, The Warnock Report, 291 BRIT. MED. J. 187, 187-89 (1985) (summarizing the Warnock Report).

${ }^{74}$ Donna M. Gitter, Am I My Brother's Keeper? The Lse of Preimplantation Genetic Diagnosis to Create A Donor of Transplantable Stem Cells for an Older Sibling Suffering from a Genetic Disorder, 13 GEO. MASON L. REV. 975, 987 (2006); Margaret F. Riley \& Richard A. Merrill, Regulating Reproductive Genetics: A Review of American Bioethics Commissions and Comparison to the British Human Fertilisation and Embyology Authority, 6 COLUM. SCI. \& TECH. L. REV. 1, 5 (2005). While an analysis of the United Kingdom's institutions may have required an analysis of European Union institutions and law, the United Kingdom, which has been categorized as "experienc[ing] a rising tide of mistrust about government institutions," voted in 2016 to exit the European Union. See NORRIS, supra note 43, at 58. As such, the analysis of the U.K.'s regulatory structure infra largely neglects the European Union's regulatory process as, as of the time that this Article is being written, the U.K. is in the process of exiting the European Union. For more on "Brexit," see sources cited supra note 45 and accompanying text. 
The U.K. has a robust system for regulating ART ${ }^{75}$ which has been described as "...perhaps the most well-developed." " Un like in the United States, where traditional ART is generally described as "minimally regulated" or "unregulated," all ART in the United Kingdom is highly regulated. ${ }^{77}$ In contrast to the lack of regulation in the United States (or unexpected subterranean regulation by the FDA), the United Kingdom created a regulatory agency, the Human Fertilisation \& Embryology Authority ("HFEA"), which regulates a number of matters related to ART. ${ }^{78}$

The HFEA was authorized by the Human Fertility and Embryology Act of $1990^{79}$ and "set up in 1991." 80 It "is the UK's independent regulator of treatment using eggs and sperm, and of treatment and research involving human embryos." ${ }^{11}$ The HFEA describes its goals as

ensur[ing] that everyone who steps into a fertility clinic, and everyone born as a result of treatment, receives high quality care. We do this by licensing, monitoring and inspecting fertility clinics ... and providing free, clear and impartial information about fertility treatment, clinics and egg, sperm and embryo donation. We also collect data about fertility treatments. ${ }^{82}$

These goals stem from the agency's enabling statute (in American parlance) as the 1990 Act (as amended) "gives the HFEA a number of statutory functions," including the licensing of fertility clinics and research centers, the maintenance of a register of adverse reactions and events and "... regulat[ing] the storage of gametes and embryos..." 83 The 1990 version of the Human Fertilisation and Embryology Act is generally referred to as "the 1990 Act (as amended)"; it was subsequently amended in $2008{ }^{84}$ The agency also promulgates requirements related to the selection of donors of reproductive tissue. ${ }^{85}$ Further, the HFEA also publishes a Code of Practice which it incorporates into its

\footnotetext{
${ }^{75}$ Kerry L. Macintosh, Teaching About the Biological Clock: Age-Related Fertility Decline and Sex Education, 22 UCLA WOMEN'S L.J. 1, 26 (2015)(citing ROBERTEDWARDS \& PATRICK STEPTOE, A MATTER OF LIFE: THE STORY OF A MEDICAL BREAKTHROUGH 11-15 (1980)).

${ }^{76}$ Steve P. Calandrillo \& Chryssa V. Deliganis, In I'itro Fertilization and the Law: How Legal and Regulatory Neglect Compromised A Medical Brealthrough, 57 ARIZ. L. REV. 311, 333 (2015)

77 See Calandrillo \& Deliganis, supra note 76, at 333; Subterrane Regulation, supra note 5, at 1240 ("Commentators have described the regulatory environment surrounding assisted reproductive technology [in the United States] as 'limited, 'minimally regulated,' and even 'the Wild Wild West.' [The article] reveals, however, that one important subset of assisted reproductive technology, the subset that contains forms of assisted reproductive technology that combine in vitro fertilization with the modification of small amounts of DNA ... is an exception to this general rule." (citations omitted)).

78 About Lis, HUMAN FERTILISATION \& EMBRYOLOGY AUTH., https://www.hfea.gov.uk/about-us/ [https://perma.cc/B9D2-A36D].

${ }^{79}$ Human Fertilisation and Embryology Act, 1990, c. 37, § 5 (Eng.).

86 Human Fertilisation and Embryology Authority Access to Anonymised Data, HUMAN FERTILISATION \& EMBRYOLOGY AutH. (Nov. 23 2011), https://data.gov.uk/dataset/lbdda00f-d661-4901-bf4c$63900011 \mathrm{cb} 0 \mathrm{~d} /$ human-fertilisation-and-embryology-authority-access-to-anonymised-data [https://perma.cc/U2HR-C5B2].

${ }^{81}$ About Lis, supra note 78.

${ }_{83}^{82}$ Id.

83 See Human Fertilisation \& Embryology Auth., AnNual Report and Accounts 2012/13 1, 8-9 (2013), http://www.hfea.gov.uk/docs/HFEA_Annual_Report_and_Accounts_2012-13.PDF [hereinafter 2013 ANNUAL REPORT]; see Human Fertilisation and Embryology Act, 1990, c. 37, \$§ 5-10 (Eng.); Calandrillo \& Deliganis, supra note 77, at 333; About L's, supra note 78.

${ }^{84}$ See 2013 ANNUAL REPORT, supr note 83, at 8. The "Human Fertilisation and Embryology Act 2008" is generally referred to as "the 2008 Act."

${ }^{85}$ See Heled, supra note 27 , at 284-85.
} 
regulation of ART, in addition to incorporating the guidelines of various physician societies, including the "...British Andrology Society and the British Fertility Society." ${ }^{86}$ The Code of Practice is intended to aid with compliance with the 1990 Act and contains a number of mandatory requirements, such as those related to counseling, informed consent and parenthood, that apply to HFEA-licensed activities. ${ }^{87}$

In 2013, the United Kingdom considered streamlining its healthcare-related bureaucracy in order to reduce administrative costs incurred by its National Health Service. ${ }^{88}$ One of the options considered was the possibility of transferring the functions of the HFEA and Human Tissue Authority to the Commission on Quality Control and the Health Research Authority. ${ }^{89}$ At the same time, the HFEA and its decisions have been criticized on a number of grounds, including those based on policy, the speed of using certain assisted reproductive technologies in humans, the use of ART, and the perspectives underlying the agency's decisions. ${ }^{90}$ In keeping with the general tendency in the United Kingdom to conduct public consultations when undertaking policy or legal changes, the UK conducted a public consultation on the continued existence of the HFEA. ${ }^{91}$ In January 2013, "the Department of Health announced that the HFEA would

86 Id. at 285; Human Fertilisation \& Embryology Auth., Code of Practice 11 (9th ed. 2019), https://www.hfea.gov.uk/media/2793/2019-01-03-code-of-practice-9th-edition-v2.pdf ("One of the ways we help licensed centres comply with the Act is by publishing the Code of Practice. This is because we have a duty under the Act to maintain a document that gives guidance about licensed activities and the people who carry them out. The Code of Practice contains regulatory principles for licensed centres, and guidance notes which provides guidance to help clinics deliver safe, effective and legally compliant treatment and research. Guidance in the Code of Practice also serves as a useful reference for patients, donors, donor-conceived people, researchers and those working in the fertility sector.") [hereinafter CODE OF PRACTICE].

${ }^{87}$ CODE OF PRACTICE, supra note 86, at 11-12 (noting that the Code of Practice contains "mandatory requirements[,] ... [,]...interpretation of mandatory requirements[,] guidance [and o]ther legislation, professional guidelines and information.").

${ }^{88}$ See Press Release, Dept. of Health, Fertility and Tissue Regulators to be Reviewed Following Consultation, (Jan. 25, 2013) (Eng.),, http://mediacentre.dh.gov.uk/2013/01/25/fertility-and-tissue-regulators-to-bereviewed-following-consultation/ [https://perma.cc/EH3C-2ZM7].

${ }^{89}$ For more information on the roles of the Human Tissue Authority, Care Quality Commission, and Health Research Authority, see id.; DeP'T OF HeAlth, GOVERNMENT RESPONSE tO THE CONSUltation ON PROPOSALS TO TRANSFER FunCTIONS FROM THE HUMAN FERTILISATION AND EMBRYOLOGY AUTHORITY $\begin{array}{llllll}\text { AND THE HUMAN } & \text { TISSUE } & \text { AUTHORITY } & \text { 6-8 }\end{array}$ https://assets.publishing.service.gov.uk/government/uploads/system/uploads/attachment data/file/212742/C onsultation_HFEA_and_HTA_government_response.pdf [hereinafter GOVERNMENT RESPONSE].. For public responses to the public consultation related to the continued existence of the HFEA, see DEP'T OF HEALTH, Consultation on Proposals to Transfer Functions From the Human Fertilisation and EMBRYOLOGY AUTHORITY AND THE HUMAN TISSUE AUTHORITY: RESPONSES (2013).

"See David Adamson, Regulation of Assisted Reproductive Technologies in the Linited States, 39 FAM. L.Q. 727, 739 (2005); Lyndsey Craven et al., Research into Policy: A Brief History of Mitochondrial Donation, 34 STEM CELlS 265, 265 (2016); Katherine Drabiak, Emerging Governance of Mitochondrial Replacement Therapy: Assessing Coherence Between Scientific Evidence and Policy Outcomes, 20 DEPAUL J. HEALTH CARE L. 1, 20 (2018); Gitter, supra note 74, at 1008; Lyria B. Moses, Linderstanding Legal Responses to Technological Change of In I'itro Fertilization, 6 MiNN. J.L. SCI. \& TECH. 505, 603 (2005) (stating "Restrictions on the freedom of clinicians to determine what is best for each individual patient in the context of multiple embryo transfer is the most common criticism of HFEA by clinics."); Riley \& Merrill, supra note 74, at 53 ("HFEA has frequently been criticized as overly 'pro-choice."); Helene S. Shapo, Frozen PreEmbryos and the Right to Change One's Mind, 12 DUKE J. COMP. \& INT'L L. 75, 99 (2002).

${ }^{1}$ Human Fertilisation \& EMBryology Auth., AnNual Report \& ACCOUnTs, Chair and Chief EXECUTIVE'S FOREWORD 4-5 (2012-2013) http://www.hfea.gov.uk/docs/HFEA_Annual_Report_and_Accounts_2012-13.PDF [hereinafter CHAR AND CHIEF EXECUTIVE'S FOREWORD];_see GOVERNMENT RESPONSE, supra note 89.). For more on the public consultation process in the United Kingdom, see UK CABINET OFFICE, CONSUltation PRINCIPLES 2018 (2018). For more on public consultations generally, see Bojan Bugaric, Openness and Transparency in Public Administration: Challenges for Public Law, 22 WIS. INT'L L.J. 483, 502-4 (2004); Andrew Edgar, 
be retained as an independent regulator... follow[ing] a public consultation in which 75 percent of respondents argued that retaining the HFEA as a specialist expert regulator was in the best interests of patients and the fertility sector." ${ }^{92}$

2. Regulation of Mitochondrial Transfer in the United Kingdom

In order to legalize the use of mitochondrial transfer in the United Kingdom,

the UK's government initiated a number of statutory and regulatory changes. The 2008 Amendment of the Human Fertilisation and Embryology Act "introduce[ed] new powers which allow for Regulations to be passed by Parliament that will allow techniques that alter the DNA of an egg or embryo to be used in assisted conception, to prevent the transmission of serious mitochondrial disease." ${ }^{93}$ The 2008 Act addresses, among other issues, the legal parentage of children conceived as a result of newer forms of ART, such as mitochondrial transfer and posthumously conceived children. ${ }^{94}$

Before approving the use of mitochondrial transfer in the United Kingdom, however, the HFEA undertook a number of scientific reviews and a five-strand public consultation. ${ }^{95}$ After a public consultation on the topic of mitochondrial transfer in March 2013, the United Kingdom's HFEA “concluded there was 'general support' for the idea and that there was no evidence that the advanced form of IVF was unsafe." 96 The UK's five-strand public consultation included a number of information gathering methods, including "...deliberative public workshops, ...[a] public representative survey,... [an] open consultation questionnaire, $\ldots$ open consultation meetings....and patient focus groups." 97

The United Kingdom's Department of Health produced draft regulations, and an amendment to the Human Fertilisation and Embryology Act was approved by the House of Lords at the end of February $2015 .{ }^{98}$ Sally Cheshire, the chairwoman of the HFEA, said:

Administrative Regulation-Making: Contrasting Parliamentary and Deliberative Legitimacy, 40 MELB. U. L. REV. 738, 751-52 (2017). For more on public consultations in the United Kingdom related to assisted reproductive technology, see Mary L. Shanley, Collaboration and Commodification in Assisted Procreation: Reflections on an Open Market and Anonymous Donation in Human Sperm and Eggs, 36 L. \& SOC'Y REV. 257, 274 n.35 (2002); Benjamin B. Williams, Screening for Children: Choice and Chance in the "Wild West" of Reproductive Medicine, 79 GEO. WASH. L. REV. 1305, 1327 (2011).

92 See Chair AND CHIEF EXeCuTIVE's ForeWORD, supra note 91, at 4-5; GOVERNMENT RESPONSE, supra note 89.

93 Human Fertilisation \& EMBryology Auth., MitochondRia RePlaCEMENT CONSUltation: Advice TO GOVERNMENT 8 (2013), https://www.hfea.gov.uk/media/2618/mitochondria_replacement_consultation__advice_for_government.pdf [hereinafter ADVICE TO GOVERNMENT]; see Joan Mahoney, Genome Mapping and Designer Babies: A Comparative Perspective, 79 UMKC L. REV. 309, 312 (2010) (discussing the scientific and social motivations for the 2008 Amendment to the 1990 Act).

${ }^{9}$ See CHAIR AND CHIEF EXeCUTIVE's FoRewORD, supra note 92, at 8; Maya Sabatello, Posthumously Conceived Children: An International and Human Rights Perspective, 27 J.L. \& HEALTH 29, 36 (2014).

"5 ADVICE TO GOVERNMENT, supra note 93, at 7.

" See James Gallagher, LK Government Backs Three-Parent $\Pi F$, BBC NEWS (June 27, 2013), www.bbc.co.uk/news/health-23079276 [https://perma.cc/5KDD-LP3F]; see also CHAIR AND CHIEF EXECUTIVE'S FOREWORD, supra note 91_(characterizing support for mitochondrial replacement as "broad"). 9 SARAH BARBER \& PETER BORDER, MITOCHONDRIAL DONATION 13 (2015), https://researchbriefings.files.parliament.uk/documents/SN06833/SN06833.pdf.

${ }^{8}$ See Brittany Shoot, 3-parent $\Pi F$ : Why Isn't it Available in the Lnited States?, THE GuARDIAN (Feb. 27, 2015), http://www.theguardian.com/sustainable-business/2015/feb/27/3-parent-ivf-us-mitochondria-dnababies [https://perma.cc/RHM9-96VA]. For more on lawmaking in the UK, see sources cited supra notes 5863. 
Britain is the first country in the world to permit this treatment, and it is a testament to the scientific expertise and well-respected regulatory regime that exists across the UK that Parliament has felt able to approve it...The HFEA has a long tradition of dealing with medical and scientific breakthroughs, ensuring that IVF techniques, pioneered in the UK and now practised across the world, can be used safely and effectively in fertility treatment. ${ }^{99}$

While notice-and-comment rulemaking is a hallmark of American administrative law, the United Kingdom's experience with mitochondrial transfer went far beyond notice-and-comment rulemaking in terms of the depth and breadth of the UK's consultation and scientific inquiry into mitochondrial transfer. ${ }^{100}$ As noted by the Parliamentary Office of Science and Technology, "[t]he techniques (matemal spindle transfer and pronuclear transfer) have been subject to three scientific reviews (2011, 2013 and a further update in 2014), [focused on safety and efficacy,] by a Human Embryology and Fertilisation Authority expert panel, an ethical review by the Nuffield Council on Bioethics and a HFEA public consultation." ${ }^{101}$ A fourth scientific review was completed in November 2016. ${ }^{102}$ The UK's Chief Medical Officer noted, on the subject of mitochondrial transfer, "[t]he only clinical tests you can do are either in rats, mice and monkeys - and those have been done - or in humans and the mothers now want to do this following those three scientific reviews." 103

As noted earlier, the HFEA public consultation consisted of five strands. ${ }^{104}$ The first strand was composed of deliberative public workshops. ${ }^{105}$ The first meetings of the deliberative public workshops focused on helping members of the public understand the science underlying mitochondrial donation techniques and mitochondrial disease, which

\footnotetext{
"See Gallagher, supra note 96.

100 Nina A. Mendelson, Rulemaking, Democracy, and Torrents of E-Mail, 79 GEO. WASH. L. REV. 1343, 134344 (2011).

101 See BARBER \& BORDER, supra note 97, at 1. For the "three scientific reviews" of mitochondrial transfer (and the 2014 addendum to the "further update in 2014"), see generally HUMAN FERTILISATION \& EMBRyology Auth., ANNEX VIII: SCIENTIFIC REVIEW of THE SAFETy AND EFFICACy OF METHOdS to AVOID MITOCHONDRIAL

DiseASE THROUGH AsSisted CONCEPTION: UpDATE (2013), https://www.hfea.gov.uk/media/2612/mitoannex_viii-science_review_update.pdf; HUMAN FERTILISATION \& EMBRYOLOGY AUTH., REVIEW OF THE SAFETy AND EFFICACY OF POLAR BODY TRANSFER TO AVOID MitochONDRIAL DisEASE ADDENDUM TO 'THird SCIENTIFIC REVIEW OF THE SAFETy and EFFiCACy of Methods to AVOID Mitochondrial DISEASE THROUGH ASSISTED CONCEPTION: 2014 UPDATE' (2014), https://www.hfea.gov.uk/media/2610/2014-10-07_-_polar_body_transfer_review_-_final.pdf; HUMAN FERTILISATION \& EMBRYOlOGY AUTH., SCIENTIFIC REVIEW OF THE SAFETY AND EFFICACY OF METHODS TO AVOID MitochondRIAL DisEASE THROUGH AsSisted CONCEPTION (2011), https://www.hfea.gov.uk/media/2613/scientific-review-of-the-safety -and-efficacy-of-methods-to-avoidmitochondrial-disease-through-assisted-conception.pdf; HUMAN FERTILISATION \& EMBRYOLOGY AUTH., THIRD SCIENTIFIC REVIEW OF THE SAFETY AND EFFICACY OF METHODS TO AVOID MITOCHONDRIAL DISEASE THROUGH ASSISTED CONCEPTION: 2014 UPDATE, https://www.hfea.gov.uk/media/2614/third_mitochondrial_replacement_scientific_review.pdf.

102 See Human FERTILISATION \& EMBR yology Auth., SCIENTIFIC REVIEW OF THE SAFETY AND EFFiCACY of Methods to Avoid Mitochondrial Disease THROUGH Assisted CONCEPTION: 2016 Update 4-5 (2016), https://www.hfea.gov.uk/media/2611/fourth_scientific_review_mitochondria_2016.pdf [hereinafter 2016 UPDATE].

${ }^{103}$ See Steve Connor, Chief Medical Officer L'rges Lords to Legalise 'Three-Parent' II F, THE INDEPENDENT (Feb. 24, 2015), http://www.independent.co.uk/news/science/chief-medical-officer-urges-lords-to-legalisethree-parent-ivf-10065833.html [https://perma.cc/Q2CM-736D].

${ }^{104}$ See ADVICE TO GOVERNMENT, supra note 93.

${ }^{105}$ See id. at $10-11$.
} 
could minimize sensationalism of press coverage. ${ }^{106}$ The "second events [of the deliberative public workshops] focused on the social and ethical issues relating to the techniques." ${ }^{107}$ The second strand of the UK's public consultation included nearly 1,000 face-to-face interviews with members of the public on a number of topics related to mitochondrial disease, treatment of genetic disease and ART. ${ }^{108}$ Third, open consultation meetings "involved a combination of small group discussions around particular issues, whole group debates, and discussion between and across the panel and the floor." 109 Fourth, the "open consultation questionnaire" permitted interested members of the public to consider information posted on a public consultation website before submitting responses to seven specific questions through the mail or online. ${ }^{110}$ Fifth, there was a patient focus group, composed of individuals who had been directly or indirectly affected by mitochondrial disease. ${ }^{111}$ The aforementioned five-strand public consultation contained a number of methods that parallel the American administrative law consultation process or that could be adapted to a public consultation in the United States on the topic of mitochondrial transfer, and ultimately, other technologies involving genetic modification.

\section{The Role of Non-Governmental Bodies}

Non-governmental bodies such as the aforementioned National Academies of Sciences in the United States and the Nuffield Council on Bioethics in the United Kingdom aid national governments in decision-making related to assisted reproductive technology, especially mitochondrial transfer. ${ }^{112}$ For example, in one of the Nuffield Council's reports, NOVEL TECHNIQUES FOR THE PREVENTION OF MITOCHONDRIAL DNA DISORDERS: AN ETHICAL REVIEW, the Nuffield Council on Bioethics "[a]s an independent body ... sought to identify the novel ethical issues raised [by mitochondrial replacement therapies], while also looking deeper into the issues which have already featured in the public debate about these techniques." 113 This Report was cited to in numerous influential documents issued by the HFEA and UK Parliamentary offices in relation to the UK Parliament's ultimate changing of the regulations to permit the use of mitochondrial transfer in the United Kingdom. ${ }^{114}$

\section{B. UNITED STATES}

\footnotetext{
${ }^{106} I d$. at $11,22$.

${ }^{107}$ Id. at 11

${ }^{108} \mathrm{Id}$.

109 Id.

110 See ADVICE TO GOVERNMENT, supra note 93, at 11.

${ }^{111} I d$.

${ }^{112}$ See infra note 160 and accompanying text (discussing the National Academy of Science's report completed at the request of the FDA); see also About, NUFFIELD COUNCIL ON BIOETHICS, http://nuffieldbioethics.org/about [https://perma.cc/494C-8ZHS] ("The Nuffield Council on Bioethics is an independent body that examines and reports on ethical issues in biology and medicine. It was established by the Trustees of the Nuffield Foundation in 1991, and since 1994 it has been funded jointly by the Foundation, Wellcome and the Medical Research Council. The Council has achieved an international reputation for advising policy makers and stimulating debate in bioethics.")

${ }^{113}$ NUFFIELD COUNCIL ON BIOETHICS, NOVEL TECHNIQUES FOR THE PREVENTION OF MITOCHONDRIAL DNA DISORDERS: AN ETHICAL REVIEW viii (2012), http://nuffieldbioethics.org/wpcontent/uploads/2014/06/Novel techniques for the prevention of mitochondrial DNA disorders compre ssed.pdf.

${ }^{114}$ See ADVICE TO GOVERNMENT, supra note 93 at 10; 2016 UPDATE, supr note 102 at 32; BARBER \& BORDER, supra note 97, at 5 (stating "information . . . to Members of Parliament in support of their parliamentary duties").
} 
While the United Kingdom was the site of the birth of the first child conceived using ART, many innovations in ART have developed in the United States. In 2014, there was significant media coverage of the work of Dr. Shoukhrat Mitalipov at the Oregon Health \& Science University in the realm of maternal spindle transfer, one of the two forms of mitochondrial transfer. ${ }^{115}$ More recently, Dr. John Zhang, a New York-based physician traveled to Mexico to prevent the transmission of Leigh Syndrome, a mitochondrial disease, using mitochondrial transfer. ${ }^{116}$ Before that in the 1990s and early 2000s, a number of American physicians were providing cytoplasmic transfer, which was similar to mitochondrial transfer, in order to improve women's fertility. ${ }^{117}$ Yet, in all of these aforementioned instances, innovation was stymied in several ways. The FDA sent letters to physicians providing cytoplasmic transfer, stating that in order to continue providing these techniques to their patients, they had to obtain approval through the FD A's investigational new drug approval process. ${ }^{118}$ In the case of more recent innovations in mitochondrial transfer, the FDA responded with continued declarations of its jurisdiction over the technique through letters to physicians and general declarations. ${ }^{119}$ Subsequently, Congressional budget riders have prohibited the agency from considering licenses for ART techniques involving genetic modification. ${ }^{120}$ This part explores both the federal and state regulation of ART (including advanced assisted reproductive technologies) in the United States.

1. The American Regulatory Framework Governing Assisted Reproductive Technology Use and Innovation

Historically, there has been little state or federal regulation of ART, which allowed the industry to develop with little regulatory oversight. ${ }^{121}$ The prevailing view is that ART in the United States is minimally regulated or unregulated; however, forms of ART involving genetic modifications are highly regulated in the United States, albeit through formally non-binding documents issued by the federal govemment that nonetheless have practically binding effects. ${ }^{122}$ For those forms of ART that are more

${ }^{115}$ Sabrina Tavemies, His Fertility Advance Draws Ire, N.Y. TIMES (Mar. 17, 2014).

116 See John Zhang et al., Live Birth Derived from Oocyte Spindle Transfer to Prevent Mitochondrial Disease, 34 REPROD. BIOMEDICINE ONLINE 361, 361-68 (2017) (discussing the use of mitochondrial donation treatment in a patient with Leigh Syndrome by Dr. John Zhang and other colleagues at the New Hope Fertility Center, which has offices in New York and Mexico).

${ }^{117}$ See Subterranean Regulation, supra note 5, at 1250, 1260; see also Charlotte Pritchard, The Girl with Three Biological Parents, BBC NEWS: MAG (Sept. 1, 2014), https://www.bbc.com/news/magazine-28986843 [https://perma.cc/HK49-M74V].

${ }^{118}$ Subterranean Regulation supra note 5, at 258. For the full letter, see id. at 1289-91.

${ }^{11}$ See Letter from Mary A. Malarkey, Dir., Office of Compliance \& Biologics Quality, Ctr. for Biologics Evaluation \& Research, U.S. Food \& Drug Admin., to John Zhang, CEO, Darwin Life, Inc. \& New Hope Fertility Center (Aug. 4, 2017), https://www.fda.gov/media/106739/download [hereinafter FDA Letter]; see also Advisory on Legal Restrictions on the L'se of Mitochondrial Replacement Techniques to Introduce Donor Mitochondri into Reproductive Cells Intended for Transfer into Human Recipient, Cellular \& Gene Therapy Products, U.S. FOOD \& DRUG ADMIN. (Mar. 16, 2018), https://www.fda.gov/biologicsbloodvaccines/cellulargenetherapyproducts/ucm570185.htm [https://perma.cc/RW6M-S9EN] ("The clinical use of [mitochondrial replacement therapy] in the United States falls within FDA's regulatory authority.") [hereinafter MRT Legal Restrictions].

12. See, e.g., FDA Letter, supra note 119; MRT Legal Restrictions, supra note 119.

${ }^{121}$ Lori B. Andrews \& Nanette Elster, Regulating Reproductive Technologies, 21 J. LEGAL MED. 35, 35-44 (2000) (providing historical overview of ART).

${ }^{122}$ See Subterranean Regulation, supra note 5, at 1241 n.1, 1259, 1270; see also Heled, supra note 27, at 247 (noting the "dearth of state law and a total lack of federal law regulating the genetic aspects of [donated reproductive tissue]"); Rosato, supra note 36, at 57,63 ("Assisted reproductive technology ("ART") has been in existence for twenty-five years with very little oversight or regulation." (citations omitted)). 
"traditional," and similar to the ART of the 1970s, such as IVF (without genetic modifications) and artificial insemination, the traditional characterization of the regulation of ART remains accurate as states and the federal government provide little regulation of ART that does not involve genetic modification. ${ }^{123}$

As noted in part II.B supra, the Fertility Clinic Success Rate and

Certification Act is the only federal statute that regulates ART. ${ }^{124}$ In spite of the existence of only one statute that applies to ART regulation, ${ }^{125}$ the FDA has used its power to stymie the use of forms of ART that involves genetic modifications in the United States.

First, the agency used notice-and-comment rulemaking to promulgate its Human Cellular and Tissue-Based Products regulation, which became a final rule in 2001. ${ }^{126}$ This final rule created a framework in which "more than minimally manipulated" tissue is subject to the agency's investigational new drug requirements. ${ }^{127}$ Despite comments received during the notice-and-comment rulemaking process stating that the term "minimal manipulation" was vague and should be eliminated, the agency retained the term and its associated framework. ${ }^{128}$ Ultimately, that framework has been applied to innovations in ART, which are characterized by the FDA as involving "more than minimal manipulation," thus requiring the use of an investigational new drug application under federal law, instead of being categorized as simply the practice of medicine. ${ }^{129}$

Subsequent to the effective date of the Human Cellular and Tissue-Based Products rule, the agency issued a number of documents, based on that regulation, stating that the agency has jurisdiction over forms of ART involving genetic modification, without clearly explaining what statutes accorded it such jurisdiction. ${ }^{130}$

${ }^{123}$ See Subterranean Regulation, supra note 5, at 1270-71 n.136.

${ }^{124}$ See 42 U.S.C. § $263 \mathrm{a}-1$ (2012).

${ }^{125}$ See id.

${ }^{126}$ See Human Cells, Tissues, and Cellular and Tissue-Based Products; Establishment Registration and Listing, 66 Fed. Reg. 5447, 5452 (Jan. 19, 2001); Tissue and Tissue Product Questions and Answers, U.S. FoOD \& DRUG ADMIN.,

http://www.fda.gov/BiologicsBloodVaccines/TissueTissueProducts/QuestionsaboutTissues/ucml01559.htm [https://perma.cc/88NS-G2XS].

${ }^{127}$ Human Cells, Tissues, and Cellular and Tissue-Based Products; Establishment Registration and Listing, 66 Fed. Reg. at 5452.

${ }^{128}$ Id. at 5457 ("Eight comments asserted that 'minimal manipulation' is vague and open to subjective interpretation, and should be eliminated. Two comments asserted that it is difficult to draw a meaningful distinction between tissues that are minimally manipulated and those that are more than minimally manipulated. One of these comments suggested that instead of the minimal manipulation criterion, FDA should propose that tissue products labeled or promoted for tissue replacement, reconstruction, or restoration of function be regulated as tissue. Another comment requested the development of guidance and noted that in light of future technological advances, a broader definition of minimal manipulation may be more appropriate."). Overall, the FDA received " 28 comments on the proposed rule as it was published in 1998 [and] over 400 comments on the donor-suitability proposed rule; many of these raised issues related to subparts A and B of part 1271." Id. at 5450. Comments related to the term "minimal manipulation" were addressed with the other comments on Comments on Subpart A: Proposed Sectionl271.10 and Section 1271.15 (Final Section 1271.10 and Section 1271.20). Id. at 5450, 5453, 5457.

${ }^{129}$ See Halted Innovation, supra note 7, at 1100.

130 See id. § 553(b)(3) ("Except when notice or hearing is required by statute, this subsection [requiring notice of proposed rulemaking] does not apply . . to interpretive rules, general statements of policy, or rules of agency organization, procedure, or practice"); see also Advisory on Legal Restrictions on the Use of Mitochondrial Replacement Techniques to Introduce Donor Mitochondria into Reproductive Cells Intended for Transfer into a Human Recipient, Cellular \& Gene Therapy Products, U.S. FOOD \& DRUG ADMIN. (Mar. 16, 2018), https://www.fda.gov/biologicsbloodvaccines/cellulargenetherapyproducts/ucm570185.htm [https://perma.cc/9STE-Q4LF]. 
These documents, issued by the FDA, were part of a larger trend in which many agency decisions escape notice-and-comment rulemaking, thereby eliminating the opportunity for the public to provide comments on proposed federal regulations and agency action. ${ }^{131}$

As numerous scholars have noted, many agencies rely upon informal methods of guidance to regulate, instead of issuing nules. ${ }^{132}$ First, informal guidance methods are not subject to public comment. ${ }^{133}$ Second, their informal nature makes it much harder for the public to rely on those mechanisms or to even know that those mechanisms exist although, at the same time, various court opinions have noted that guidance documents have binding effect even though they are not subject to the notice-and-comment process and contain disclaimers stating that they are not binding. ${ }^{134}$ Although assisted reproductive technology providers have not commenced litigation related to the FDA's pronouncements on the effects "minimal manipulation" framework as detailed in nonlegislative documents to assisted reproductive technology, it is worth noting that a significant amount of administrative law literature and court decisions have focused on ascertaining when agency pronouncements should be categorized as legislative rules, which are subject to notice-and-comment rulemaking, as opposed to as interpretive or non-legislative rules which are not. ${ }^{135}$ While some regulated entities appreciate informal agency pronouncements because those announcements permit them to perhaps cease actions that might result in domestic enforcement actions, ${ }^{136}$ others are troubled by these

\footnotetext{
131 See William N. Eskridge Jr., Statutes, Regulation, and Interpretation: Legislation and ADMINISTRATION IN THE REPUBLIC OF STATUTES 713-16, 838 (2014).

${ }^{132}$ Id. at 838; Richard A. Epstein; The Role of Guidances in Modern Administrative Procedure: The Case for De Novo Review, 8 J. OF LEG. ANAL YSIS 47, 47-48, 58-83 (2016) (discussing the evolution of the current use of guidance documents by administrative agencies); David L. Franklin, Legislative Rules, Nonlegislative Rules, and the Perils of the Short Cut, 120 YALE L.J. 276, 278, 286-89 (2010); Mark Seidenfeld, Substituting Substantive for Procedural Review of Guidance Documents, 90 TEX. L. REV. 331, 332-8 and 340-4 (2011).

${ }^{133}$ Epstein, supra note 132, at 47.

${ }^{134}$ Halted Innovation, supra note 7, at 1098 .

${ }^{135}$ See e.g. Mark Seidenfeld, Substituting Substantive for Procedural Review, 90 TEX. L. REV. 331, 332 and 350-2; Id. at 360-1 ("For interpretive rules, the message from the courts is that the weaker the link between the interpretation and the text of the statute or regulation being interpreted, the less likely a court is to allow the agency to announce the interpretation by guidance document."); Perez v. Mortgage Bankers Ass'n, $135 \mathrm{~S}$. Ct. 1199, 1208 (2015); Appalachian Power Co. v. EPA, 208 F.3d 1015, 1021 and 1024-5 (2000); General Electric Co. v. EPA, 290 F.3d 377, 380-85 (2002); Nat'l Min. Ass'n v. Sec'y of Labor, 589 F.3d 1368, 137173 (2009). For more on the disparate tests used to ascertain whether a document that the agency has classified as a non-legislative rule actually required notice-and-comment because it actually should have been issued as a legislative rule, see e.g. Kristin Hickman, Linpacking the Force of Law, 66 VAND. L. REV. 465, 480-84 (2013); Id. at 503 at n. 205, 513; David L. Franklin, Legislative Rules, Nonlegislative Rules, and the Perils of the Short Cut, 120 YALE L. J. 276, 284 (2010)(discussing the concern that agencies "strategically" use nonlegislative documents to avoid the notice-and-comment rulemaking process and the various tests that courts use to ascertain whether a "document promulgated without notice and comment is really a legislative rule and is therefore procedurally invalid," including the "legal effect test" and the "substantial impact test."). See also Kelley v. E.P.A., 15 F.3d 1100, 1108 (D.C. Cir. 1994); Appalachian Power Co. v. EPA ("We must still look to whether the interpretation itself carries the force and effect of law, ..or rather whether it spells out a duty fairly encompassed within the regulation that the interpretation purports to construe" citing to Paralyzed Veterans v. D.C. Arena L.P., 117 F. 3d 579, 588 (D.C. Cir. 1997). See also infra note 131.

${ }^{136}$ Subterranean Regulation, supra note 5, at 1259-60 (describing the reactions of physician-researchers after receiving letters from the FDA which was to cease their research or medical practice or move it abroad). Beyond the reactions of physicians and researchers after receiving letters from the FDA, examining the agency's letters through the lens of the tests that courts have used to ascertain whether guidance documents should be treated as legislative rules, many aspects of those agency rules lend themselves to arguments that the agency documents explaining the application of the "minimal manipulation rule" should be treated as legislative rules as opposed to non-legislative rules. For example, while the FDA's letters to researchers in 2001 did not specifically state that their specific work was subject to the FDA's regulation, the letter used mandatory language: "The use of such genetically manipulated cells (and/or their derivatives) in humans
} 
informal agency pronouncements because they create an uncertainty, having provided an agency view in a non-binding document. ${ }^{137}$ The goal of notice-and-comment regulations is said "to discipline agency decision making and promote public-regarding (i.e., nonarbitrary) action by agencies," although many types of decisions, including nonenforcement decisions and decisions supported by guidance documents, are not subject to public comment. ${ }^{138}$

Congressional budget riders can also stymie innovation. Congress has enacted (and renewed annually) budget riders that restrict the funding of certain embryonic stem cell research projects since 1996, and the FDA's review of applications involving genetic modification since $2015 .{ }^{139}$ These riders have been enacted without a defined consultation with the public on these matters and in at least one case, without any

constitutes a clinical investigation and requires submission of an Investigational New Drug application (IND) to FDA." Letter from U.S. Food \& Drug Admin., to Sponsors/Researchers - Human Cells Used in Therapy Involving the Transfer of Genetic Material by Means Other Than the Union of Gamete Nuclei (May 6, 2009); see e.g.Ronald M. Levin, Rulemaking and the Guidance Exemption, 70 ADMIN. L. REV. 263, 294-98 (2018) (discussing courts' analysis of mandatory language in litigation related to whether agency documents are in fact legislative rules despite being labeled otherwise). The reactions of physicians and researchers to the FDA's letters which purport to "advise" addressees of the agency's jurisdiction and requirements indicates that those letters and the agency's interpretations have "the force and effect of law." See Am. Mining Cong. v. Mine Safety \& Health Admin., 995 F.2d 1106, 1108-09 (D.C. Cir. 1993). For those who received the agency's letters in 2001, they stopped providing the technique in the United States. Similarly, in 2017, Dr. John Zhang, who provided the technique in Mexico, to avoid the U.S. regulatory system, later submitted an investigational new drug application so as to offer the technique in the United States in accordance with the FDA's statements of what was required by the statute (as explained through the Human Cellular and Tissuebased Products rule and the agency's subsequent pronouncements in non-legislative documents). See supra note 116 and accompanying text. In sum, the effect of these agency statements regarding its jurisdiction over forms of assisted reproductive technology involving genetic modification is that researchers adhere to the FDA's framework, as explained in guidance documents and either cease offering (and researching) the technique altogether or cease offering the technique in the United States specifically in order to avoid the FDA's jurisdiction. Thus, these agency interpretations carry the "force and effect of law." See Appalachian Power Co. v. EPA, 208 F.3d 1015, 1024 (2000); but see Perez v. Mortgage Bankers Assoc., 135 S. Ct. 1199 , 1207-11 (2015) (explaining that agencies do not have to use notice-and-comment rulemaking when "significantly alter[ing] a prior, definitive interpretation of a regulation" as was previously required by Paralyzed I'eterans);). But see Gwendolyn McKee, Judicial Review of Agency Guidance Document: Rethinking the Finality Doctrine, 60 ADMIN. L. REV. 371, 380, 390-97 7(discussing the FDA's statutory disclaimer related to the binding nature of guidance documents and litigation related to guidance documents in the context of the FDA). For post-Perez discussion of various tests still used to interpret whether an agency decision is a legislative or non-legislative rule, see generally Ronald M. Levin, Rulemaking and the Guidance Exemption, 70 ADMIN. L. REV. 263 (2018); Cass R. Sunstein, "Practically Binding": General Policy Statements and Notice-and-Comment Rulemaking, 68 ADMIN. L. REV. 491, 505-088 (2016).

${ }^{137}$ See Subterranean Regulation, supra note 5.

${ }^{138}$ See Deacon, supra note 41 , at 1591.

139 See George Q. Daley, Missed Opportunities in Embryonic Stem-Cell Research, Perspective, 351 N. ENG. J. MED. 627, 628 (2004) ("Proposed in 1996 by Representative Jay Dickey (R-Ark.) as a rider on the appropriations bill for the Department of Health and Human Services and renewed every year since, the Dickey[-Wicker] Amendment prohibits federal engagement in a field of research pertaining to the nature of the human embryo, its disorders of development, and the derivation of new human embryonic stem-cell lines. Although most embryos created in vitro during fertility procedures are deemed unsuitable for pregnancy and are discarded, federal funds may not be used to ascertain what went wrong."); FDA Letter, supra note 119 ("Since December 2015, the United States Food and Drug Administration (FDA) has been prohibited by Congress in provisions in annual federal Appropriations Acts from using funds to accept IND submissions for clinical investigations that involve 'a human embryo ... intentionally created or modified to include a heritable genetic modification."); see also The Consolidated Appropriations Act, 2017, Pub. L. No. 115-31, 131 Stat. 173 (2017). For more on the aforementioned Consolidated Appropriations Act provision, see generally I. Glenn Cohen \& Eli Y. Adashi, The FDA is Prohibited From Going Germline, 353 SCIENCE 545 (2016). 
discussion of the rider itself at all. ${ }^{140}$ For example, Professor June Carbone noted in 2010 , " $[\mathrm{g}]$ iven the federal ban on funding embryo research, any preapproval process is likely to delay if not permanently stall the development of new techniques." ${ }^{141}$ Even though some embryonic stem cell research is now federally funded, it is subject to a number of limitations, including limits on available stem cell lines for research and federal appropriations restrictions like the Dickey-Wicker Amendment, which aims to prevent research on embryos that can result in their destruction. ${ }^{142}$

Thus, Congressional action suffers from a lack of discourse on the ethical and social issues surrounding stem cell research and forms of ART. ${ }^{143}$ In the case of mitochondrial transfer, although this article focuses on the varying approaches of the United States and United Kingdom regarding mitochondrial transfer, this form of ART has been offered to patients in other countries, including Mexico. ${ }^{144}$ The fact that a New York based physician traveled to Mexico to provide mitochondrial transfer to a couple was the subject of media attention not only after the successful birth of a child, but also in 2017 when the FDA denied the application of the physician for an investigational new drug application, citing a federal budget rider that prevented them from expending funds related to applications for investigational new drug applications involving genetic modification. ${ }^{145}$

\footnotetext{
140 For more on the "scant" legislative history of the Dickey-Wicker Amendment and the surrounding discussion, see Kerry L. Macintosh, Psychological Essentialism and Opposition to Human Embryonic Stem Cell Research, 18 J. TECH. L. \& POL'Y 229, 252-57 (2013); see also Eli Y. Adashi \& I. Glenn Cohen, Mitochondrial Replacement Therapy: Lnmade in the LSA, 317 JAMA 555, 574-75 ("The congressional record is mum on the identity of the sponsor or sponsors of the ban ['which comprises Section 749 of the Consolidated Appropriation Act of 2016'], and the precise motives for crafting it remain equally uncertain. The ban's enactment was all but guaranteed by the complete absence of discussion before its passage or at any time thereafter, and by its inclusion in a must-pass omnibus appropriation bill."); Kiyan Bigloo, Aggregation of Powers: Stem Cell Research and the Scope of Presidential Power Examined Through the Lens of Executive Order Jurisprudence, 18 PSYCHOL. PUB. POL'Y \& L. 519, 522-26 (2012); Advisory on Legal Restrictions on the Lise of Mitochondrial Replacement Techniques to Introduce Donor Mitochondria into Reproductive Cells Intended for Transfer into a Human Recipient, U.S. FOOD \& DRUG ADMIN. (Mar. 16, 2018), https://www.fda.gov/biologicsbloodvaccines/cellulargenetherapyproducts/ucm570185.htm [https://perma.cc/9STE-Q4LF] ("Since December 2015, Congress has included provisions in annual federal appropriations laws that prohibit FDA from accepting applications for clinical research using MRT. Therefore, clinical research using MRT in humans cannot legally proceed in the United States. FDA maintains the authority to investigate and take enforcement action in the event that it becomes aware of noncompliance with the laws and regulations administered by FDA.").

${ }^{141}$ June Carbone, Negating the Genetic Tie: Does the Law Encourage Lnnecessary Risks?, 79 UMKC L. REV. 333,354 (2010).

${ }^{142}$ See George Annas, Resurrection of Stem-Cell Funding Barrier - Dickey-Wicker in Court, 363 N. ENG. J. MED. 1687, 1687-8 (2010) ("The amendment, known as the Dickey-Wicker amendment, provides that no federal funds can be expended by the National Institutes of Health $(\mathrm{NIH})$ for '(1) the creation of a human embryo or embryos for research purposes; or (2) research in which a human embryo or embryos are destroyed, discarded, or knowingly subjected to risks of injury or death.' It has been added to NIH appropriations bills every subsequent year, just as the Hyde Amendment restricting abortion funding is added."); Stem Cell Information Home Page, 2016, NAT'L INST. OF HEALTH, https://stemcells.nih.gov/research/newcell_qa.htm [https://perma.cc/5YUZ-DR5W] ("No federal funds may be used, either by an awardee or a sub-recipient, to support research using derivatives of human embryonic stem cell lines (hESCs) that are not listed on the NIH Human Embryonic Stem Cell Registry, with the exception described below."); see also FDA Letter, supra note 119.

${ }^{143}$ See Eli Y. Adashi \& I. Glenn Cohen, Preventing Mitochondrial Diseases: Embryo- Sparing DonorIndependent Options, Opinion, 24 TRENDS IN MOLECUlAR MED. 449, 450 at Box 2 (2018) (citing to the "theological, ethical, and safety concerns surrounding mitochondrial transfer").

${ }^{144}$ See Michelle Roberts, First 'Three Person Baby'Baby' Born Using New Method, BBC NEws (Sept. 27, 2016), https://www.bbc.com/news/health-37485263 [https://perma.cc/R5Q2-QCZ4].

${ }^{145}$ See FDA Letter, supra note 119.
} 
While much has been written about the risk of agencies being captured by the industries that they regulate, the example of ART regulation in the United States raises an additional variation on agency capture. ${ }^{146}$ In the realm of traditional ART and advanced assisted reproductive technologies, the problem is not capture by the industry (with the industry being the fertility industry or perhaps providers of ART), but perhaps a type of undue political influence by the executive or groups motivated by specific, conservative political or social views. For example, issues that tends to surface in connection with the use of ART, especially innovative ART, are ethical debates related to the morality of destroying embryos and fetuses and political debates related to the "personhood" movement, which often surfaces decisions related to the regulation of techniques that could destroy embryos or fetuses. ${ }^{147}$

The FDA has acknowledged the existence of social and ethical issues in the realm of ART; however, the agency does not create fora for the discussion of those issues. For example, at a 2014 FDA Advisory Committee meeting at the 2014 FDA Cellular, Tissue, and Gene Therapies Advisory Committee meeting, on the topic of mitochondrial transfer, an FDA employee stated that

[t]he FDA recognizes [that there are] moral, ethical, and social policy issues related to genetic modification of eggs and embryos, and that these issues have the potential to affect regulatory decisions. However, these issues are outside of the scope of this advisory committee meeting. ${ }^{148}$

In spite of the acknowledgment that ethical and social policy issues could "affect regulatory decisions[,]" there was no further identification of what exactly those "moral, ethical, and social policy issues" were or a subsequent meeting to discuss these issues generally or how they might "affect regulatory decisions" specifically. ${ }^{149}$ By not discussing the moral, ethical, and social policy issues that can impact regulatory decisions, the administrative state allows conservative moral, ethical, and social policy issues to be the default view of the administrative state: conservative perspectives would desire the halting of innovation in ART and the current system supports that goal by not assessing whether other views might be relevant (or prevalent). At least in the realm of ART, and also a number of associated technologies including gene editing and technologies that result in germline modifications, social groups or at the very least,

\footnotetext{
${ }^{146}$ Deacon, supra note 41, at 1601; Lyria B. Moses, Lnderstanding Legal Responses to Technological Change: The Example of in I"itro Fertilization, 6 MINN. J.L. SCI. \& TECH. 505, 581-82 (2005).

${ }^{147}$ See June Carbone \& Naomi Cahn, Embryo Fundamentalism, 18 WM. \& MARY BILL RTS. J. 1015, 1017-18 (2010); I. Glenn Cohen \& Eli Y. Adashi, Embryo Disposition Disputes: Controversies and Case Law, 46 HASTINGS CTR. REP. 13, 15-16 (2016); Janet L. Dolgin, Embryonic Discourse: Abortion, Stem Cells, and Cloning, 31 FLA. ST. U. L. REV. 101, 104-06, 146 (2003); Michele Goodwin, Fetal Protection Laws: Moral Panic and the New Constitutional Battlefront, 102 CAL. L. REV. 781, 785 (2014); King, supra note 27, at 323 ("Political debate over embryo creation and destruction of ten causes people to retreat to theirfirmly entrenched positions on abortion, which contributes significantly to the regulatory stalemate with respect to ART in the United States." (citation omitted)); Maya Manian, Lessons from Personhood's Defeat: Abortion Restrictions and Side Effects on Women's Health, 74 OHIO ST. L.J. 75, 77 (2013); Mary Ziegler, Beyond Balancing: Rethinking the Law of Embryo Disposition, 68 AM. U. L. REV. 515, 523-24 (2018).

${ }^{148}$ U.S. FOOD \& DRUG ADMIN., TRANSCRIPT OF CENTER FOR BIOlOgiCs EVAlUation AND RESEARCH, Cellular, Tissue, and Gene Therapies Advisory Committee Meeting \#59 13 (2014) [hereinafter MEETING \#59 TRANSCRIPT].

${ }^{149}$ Id.; see Subterranean Regulation, supra note 5, at 1271-74.
} 
conservative social views, have managed to capture the regulatory process. ${ }^{150}$ If the federal govemment is going to continue to make decisions that likely involve some sort of ethical viewpoint, it is important to note that different polities have different ethical views. Thus, to the extent that administrative agencies are seen as more transparent than Congress, one option is to proceed in a manner that allows for that transparency through notice-and-comment, instead of allowing agency staff to make regulatory decisions related to assisted reproductive technology without public input.

In addition to federal regulation, there are numerous state statutes that address ART. ${ }^{151}$ Some states have mandated insurance coverage of fertility treatments or the offer of insurance coverage of fertility treatments. ${ }^{152}$ Some states have clarified the extent to which insurance coverage does or does not mandate coverage of fertility treatments. ${ }^{153}$ States have also enacted statutes requiring that fertility clinics inform patients of the clinics' success rates related to the success of fertility treatments. ${ }^{154}$ Just as states can influence other states, they can also impact the federal government. ${ }^{155}$ For example, many scholars have noted that the Patient Protection and Affordable Care Act was based on the state of Massachusetts' insurance scheme. ${ }^{156}$ Similarly, in the realm of ART, the federal government now provides insurance coverage for infertility treatments (including ART) for certain members of the military with service-related disabilities, although ART remains otherwise uncovered at the federal level. ${ }^{157}$

\footnotetext{
150 Wolf et al., supra note 8, at 73 ("The FDA has also recognized ethical and social policy issues related to genetic modification of eggs and embryos that will likely affect regulatory decisions."); NIH Statement on NIH Funding on Research L'sing Gene-Editing Technologies in Human Embryos, NAT'L INST. OF HEALTH (Apr. 28, 2015), http://www.nih.gov/about-nih/who-we-are/nih-director/statements/statement-nih-fundingresearch-using-gene-editing-technologies-human-embryos [https://perma.cc/4WK9-L246] ("However, NIH will not fund any use of gene-editing technologies in human embryos. The concept of altering the human germline in embryos for clinical purposes has been debated over many years from many different perspectives, and has been viewed almost universally as a line that should not be crossed.").

${ }^{151}$ See Sonia M. Suter, The "Repugnance" Lens of Gonzales v. Carhart and Other Theories of Reproductive Rights: Evaluating Advanced Reproductive Technologies, 76 GEO. WASH. L. REV. 1514, 1516 (2008) (discussing the role of states in regulating assisted reproductive technology).

${ }^{152}$ See State Laws Related to Insurance Coverage for Infertility Treatment, NAT'L CONFERENCE STATE LEGISLATURES (Apr. 27, 2018), http://www.ncsl.org/research/health/insurance-coverage-for-infertilitylaws.aspx\#1 [https://perma.cc/Z9TX-XU9U] (providing "state laws that require insurers to either cover or offer coverage for infertility diagnosis and treatment").

${ }^{153}$ LA. REV. STAT. § 22:1036 (2009) (describing "[p]rohibited exclusion of coverage of correctable medical conditions on basis of infertility"); MINN. STAT. § 256B.0625(13)(a) (2018) (stating "[m]edical assistance covers drugs, except for fertility drugs when specifically used to enhance fertility").

${ }^{154}$ See Calandrillo \& Deliganis, supra note 76, at 330 (citing VA. CODE $§ 54.1-2971.1$ ).

${ }^{155}$ Miriam Seifter, States as Interest Groups in the Administrative Process, 100 VA. L. REV. 953, 993-94 (2014) ("Phrased another way, federal agencies can work toward fulfilling their expertise-oriented role by harnessing the information production machine of the federal system--not from abstract arguments regarding principles of federalism, which may well be beyond the administrative ken, but from the specific, diverse experiences and information generated by individual states." (citations omitted)).

156 See Gillian E. Metzger, Federalism Linder Obama, 53 WM. \& MARY L. REV. 567, 602 (2011); Stephen M. Weiner, Payment Reform After PPACA: Is Massachusetts Leading the Way Again?, 11 Y ALE J. HEALTH POL'Y L. \& ETHICS 33, 33, 33 n.3 (2011).

157 See Dep't. Veterans AfFs., Veterans Health AfFairs Directive 1332: InFERTILity EValuation AND TREATMENT 1-2 (2017), https://www.va.gov/vhapublications/ViewPublication.asp?pub_D=5431 [https://perma.cc/FDM9-V5G9] ("establish[ing] policies and procedures for providing infertility evaluation and treatment to Veterans enrolled in the Department of Veterans Affairs (VA) healthcare system."); see generally Katie Falloon \& Philip M. Rosoff, Who Pays? Mandated Insurance Coverage for Assisted Reproductive Technology, 16 AM. MED. Assoc. J. OF ETHICS 63, 63 (2014) ("Currently, only about a third of states have mandated insurance coverage of infertility treatment, but the vast majority of health insurance plans in other states do not offer coverage; hence, most people pay out of pocket. Furthermore, Medicaid does not pay for ART anywhere in the US" (citations omitted)); Assisted Reproductive Services, TRICARE (Oct.
} 
In addition to professional societies in the United States, just as in the United Kingdom, non-govemmental bodies in the United States provide useful advice to govemmental and professional bodies. ${ }^{158}$ While innovation in ART has been delayed, at least as it relates to ART involving genetic modifications at the federal level, there is still discussion of the techniques by scientists, scholars, the media, and ethicists, but that discussion does not include those in federal govemment who would be making decisions related to the clinical use of ART. In the United States, the closest that the public has had to a centralized public discourse in health care on new techniques involving genetic modification is a National Academy of Sciences Report. ${ }^{159}$ At the FDA's request, the National Academy of Sciences convened a committee that wrote a report on the "ethical, social, and policy issues" implicated by the use of mitochondrial transfer. ${ }^{160}$ The National Academy of Science's Institute of Medicine's 2016 report recommended the use of mitochondrial transfer under specific conditions. ${ }^{161}$ Nonetheless, a public consultation on ART involving genetic modification still has not occurred and advanced assisted reproductive technology innovation continues to be hindered by the American administrative state.

\section{IMPLICATIONS OF THE UNITED STATES' DEMOCRATIC DEFICIT}

There are at least three broader implications of the American democratic deficit in ART innovation. First, the regulation of advanced assisted reproductive technologies by an administrative agency without public input undermines a number of administrative law values such as transparency, legitimacy, and accountability. ${ }^{162}$ Second, the lack of transparency and public involvement has permitted political concerns to affect scientific decision-making as agency employees are able to obfuscate the impact of political and social concerns on regulatory decision-making, especially when science is the subject of the regulatory regime. Third, as a matter of outcome, a comparative analysis reveals that regulation in the United Kingdom has encouraged innovation, which nuns counter to the prevailing view that regulation had adverse effects on innovation, whereas in the

\footnotetext{
3, 2018), https://www.tricare.mil/CoveredServices/IsItCovered/AssistedReproductiveServices [https://perma.cc/6VVR-D292] ("To be medically necessary means it is appropriate, reasonable, and adequate for your condition. and combined with natural conception.").

158 See sources cited infra note 160 and accompanying text (discussing the National Academy of Science's report completed at the request of the FDA).

159 THE NAT'L ACADS. OF SCI., ENG'G \& MED., MitochondRial RePlaCEMENT TeCHNiQues: EthiCAL, SOCIAL, AND POLICY CONSIDERATIONS (2016) [hereinafter MRT REPORT]. For a summary of the 2016 National Academy of Sciences report, see Adashi \& Cohen, supra note 143, at 450 Box 2.

160 MRT REPORT, supra note 159, at ix, 2 ("The proposed investigation and potential clinical use of mitochondrial replacement techniques (MRT) raises a novel collection of ethical, social, and policy issues. At the request of the U.S. Food and Drug Administration (FDA), the National Academies of Sciences, Engineering, and Medicine convened a committee with diverse interdisciplinary expertise and a range of backgrounds to examine and analyze these issues, make recommendations regarding whether and how to go forward with MRT, and elaborate principles for initial clinical investigations involving these novel techniques for avoiding some types of inherited mitochondrial DNA (mtDNA) diseases.").

${ }^{161}$ Id. at xv-xi.

${ }^{162}$ See Richard A. Bierschbach \& Stephanos Bibas, Notice-and-Comment Sentencing, 97 MINN. L. REV. 1, 20 (2012); Seifter, supr note 19, at 1308; Evan J. Criddle, When Delegation Begets Domination: Due Process of Administrative Lawmaking, 46 GA. L. REV. 117, 123 (2011); Rose-Ackerman, supra note 21, at 439; Seifter, supra note 19 , at 1308
} 
United States, regulation has operated to the detriment of innovation in the realm of advanced assisted reproductive technologies. ${ }^{163}$

There are a number of aspects of American regulation of ART that defy the traditional administrative law goals. Transparency is one of the goals of administrative law that often surfaces in the literature analyzing the actions of administrative agencies. ${ }^{164}$ For example, the Administrative Procedure Act contains statutory requirements including "notice-and-comment" rulemaking procedures which operate to provide democratic inputs into the administrative process. ${ }^{165}$ To the extent that one of the goals of administrative law and constitutional law is to "reconcile established legal traditions with pragmatic efforts to better balance expertise and accountability with the protection of individual rights," the current system has led to a lack of expertise, accountability, and protection of individual rights in the realm of advanced assisted reproductive technology innovation. ${ }^{166}$

While administrative law, especially in the United States, purports to address the detailed implementation of the legislature's directives, administrative law "also concerns the democratic legitimacy of govemment policymaking. A fair and open policymaking process helps democratic citizens hold modern govemment accountable in the face of demands for delegation and regulation, both within and beyond the state." 167 Yet, as noted in parts II and III supra, a large piece of the "[f]air and open policymaking process" is missing in the regulation of ART in the United States. ${ }^{168}$

Even analyses of the federal administrative state that do not use the term "democratic deficit" describe the federal administrative state using characteristics that are similar to those that exist in countries with democratic deficits. For example, Nina Mendelson notes that there is an opaqueness to the operation of administrative agency decision-making and that this "... lack of adequate transparency has significant adverse consequences, both for the appropriateness of presidential influence and for the legitimacy of agency decision making." ${ }^{169}$ The lack of transparency, as it relates to European Union decision-making, has often surfaced in criticisms of the European Union. ${ }^{170}$ Similarly, from a domestic perspective, a lack of transparency may lead to a concern that agency actions suffer from a lack of "legitimacy." 171 In turn, a lack of legitimacy can also lead to a lack of accountability as, the more difficult it is to see what

\footnotetext{
${ }^{163}$ See Marchant, supra note 20, at 256 ("Administrative agencies are required to partake in extensive, procedurally time-consuming activities geared toward public participation and judicial review before setting final rules - a lengthy, time-consuming effort that is not in harmony with the speed of innovation." (citation omitted)).

${ }^{164}$ See Farber \& O'Connell, supra note 19, at 1337.

${ }^{165}$ See 5 U.S.C. § 553 (2012); see also Thomas O. Sargentich, The Critique of Active Judicial Review of Administrative Agencies: A Reevaluation, 49 ADMIN. L. REV. 599, 638 (1997) (highlighting "the transparency of notice-and-comment rulemaking process"); Seifter, supra note 19, at 1308 ("As the thousands of regulations promulgated each year 'wield[] vast power and touch[] almost every aspect of daily life,' the notice-andcomment process under section 553 of the Administrative Procedure Act (APA)--the most well-known and heralded form of administrative participation, in which interested persons may comment on proposed rules-has been celebrated as 'a crucial way to ensure that agency decisions are legitimate, accountable, and just."' (citations omitted)).

166 See Rose-Ackeman, supra note 21, at 439. For more on the concept of "expertise" in administrative law and the idea that agencies embody subject-specific expertise over the fields that they regulate, see Seifter supra note 19, at 1325-29.

${ }^{167}$ See Rose-Ackerman, supra note 21, at 436.

${ }^{168} \mathrm{Id}$.

169 Mendelson, supra note 40, at 1159.

170 See supra Part III.B.

${ }^{171}$ See Bierschbach \& Bibas, supra note 162, at 20; Mendelson, supra note 40, at 1159.
} 
has influenced a decision, the more difficult it is to hold an actor (or actors) accountable. ${ }^{172}$ In sum, analyses of the democratic deficit correspond to analyses of the extent to which the goals of administrative law are actually being carried out in the dayto-day operation of the administrative state.

The American democratic deficit in ART innovation is also significant because without it, it is possible that there is less of a "check" on political concerns that might affect an administrative agency's decision-making. ${ }^{173}$ The impact of policy (or politics) on regulatory decision-making is an issue that is salient in many scientific areas beyond ART. ${ }^{174}$ There is a concern about "political manipulation of scientific research." 175 Specifically, the fear is that "political views submerged in the process of executive supervision may work themselves out through pressure on an agency to skew its scientific or technical findings." $" 176$

In the realm of FDA regulation, the regulatory history of Plan B, which spanned across two Presidential administrations, revealed the extent to which political pressure could affect regulatory decisions, especially regulatory decisions that are supposed to be made on the basis of safety and efficacy. ${ }^{177}$ Plan B, an emergency contraceptive that was previously a prescription drug, was accompanied by substantial data indicating its safety and effectiveness (along with that of its generic drug equivalents), coupled with its suitability for designation as an over-the-counter, instead of a prescription drug. ${ }^{178}$ There were many aspects of the FDA's 12-year process of converting "Plan B and its generic equivalents" from prescription to over-the-counter status that indicated the influence of politics over scientific decision-making, including the FDA Commissioner's statement that the FDA would not act in accordance with scientific evidence indicating that the drug "should be approved for nonprescription use for all females of child-bearing potential" in the "first time the Secretary of HHS had ever overruled an FDA decision on an OTC switch." ${ }^{179}$ Nonetheless, in a multi-year regulatory process, accompanied by a U.S. Govemment Accountability Office ("GAO") report (at the behest of members of Congress concerned about the influence of politics over the regulatory process), the purposeful inclusion of individuals with anti-abortion

\footnotetext{
${ }^{172}$ See Bierschbach \& Bibas, supra note 162, at 20 " A central concept [in administrative law] is participation, the idea that citizens should have some input into agency decisions. Public participation, of course, is not the only way to check agency abuses. But it is a crucial way to ensure that agency decisions are legitimate accountable, and just. [It also] blend[s] democracy with agency expertise and judicial oversight [along with] legitimacy and accountability concerns."); Mendelson, supra note 40, at 1159.

${ }_{173}$ Mendelson, supra note 40 , at 1155 .

${ }^{174}$ See RESCUING SCIENCE FROM POLITICS: REgUlLation AND tHe Distortion OF SCIENTIFIC RESEARCH 28197 (Wendy Wagner \& Rena Steinzor, eds. 2016); Evan J. Criddle, Chevron's Consensus, 88 B.U. L. REv. 1271, 1287-88 (2008).

${ }^{175}$ Mendelson, supra note 40 , at 1143 .

${ }^{176} \mathrm{Id}$. at 1144.

${ }^{177}$ See Lisa Heinzerling, The FDA 's Plan B Fiasco: Lessons for Administrative Law, 102 GEO. L. J. 927, 93839 (2014) ("Twelve years passed between the petition of private citizens and public health and medical organizations to the FDA to approve nonprescription status for levonorgestrel-based emergency contraceptives and a court order that the FDA do so. ... Much happened during this time...[T] he FDA passed through two different presidential administrations. Through it all, the FDA remained steadfast on one point: it would not, despite all of the scientific evidence indicating it was the right thing to do, allow unrestricted access to all levonorgestrel-based emergency contraception.").

${ }^{178}$ Id.; see Kathryn A. Watts, Controlling Presidential Control, 114 MICH. L. REV. 683, 708 (2016) (providing the statement of FDA Commissioner Hamburg: "[i]t is our responsibility at FDA to approve drugs that are safe and effective for their intended use based on the scientific evidence").

${ }^{179}$ Heinzerling, supra note 177, at 947-48; Gardiner Harris, Morning After Pill Is Cleared for Wider Sales, N.Y. TIMES, Aug. 24, 2006, at Al.
} 
perspectives on an FDA Advisory Committee, the resignations of multiple career FDA officials, and federal litigation, it became evident that the FDA's decision to not approve the designation of Plan B and similar drugs as an over-the counter-medicine was driven by political considerations, including the influence of the "White House and "constituents who would be very unhappy with... an over-the-counter Plan B."' 180 The analysis of these actions also emphasized the "clandestine" attempts of the Executive Branch to influence the FDA and the lack of transparency attributed to many FDA decisions and processes. ${ }^{181}$ While Plan B was eventually approved for over-the-counter use, the FDA's inclusion of political views in the regulatory process led to significant concern over the independence of the agency and the legitimacy of its decisions. ${ }^{182}$

While the American federal govemment has had little response to the American democratic deficit in ART innovation, the states have responded in connection to research issues that often implicate issues related to ART, such as embryo destruction. The destruction of embryos in connection with research related to embryonic stem cells has led to significant controversy surrounding ART and stem cell research in the United States. ${ }^{183}$

Analyses of decision-making in the states have also focused on the existence of the "democratic deficit." ${ }^{184}$ Those analyses have found that a "democratic deficit" also exists in the states, but states are seen as being more responsive to citizen requests simply by virtue of the fact that in some states, citizens can participate in referenda and ballot initiatives. ${ }^{185}$ Additional analyses have also found that in spite of the "democratic

180 Naomi Cahn \& June Carbone, Family Classes: Rethinking Contraceptive Choice, 20 U. FLA. J.L. \& PUB. POL'Y 361, 382 (2009); Watts, supra note 178, at 708; Alastair J.J. Wood et al., A Sad Day for Science at the FDA, 353 N. ENG. J. MED. 1197, 1197-98 (2005); see Heinzerling, supra note 177, at 930-58; see also Tummino v. Torti, 603 F. Supp. 2d 519, 523-24, 544-45, 548 (E.D.N.Y. 2009) ("While it may have been rational for the FDA to consider adolescent cognitive development in its evaluation of Plan B as an OTC drug, plaintiffs have presented unrebutted evidence that the FDA's focus on these behavioral concerns stemmed from political pressure rather than permissible health and safiety concerns.").

${ }^{181}$ Cahn \& Carbone supra note 180, at 381-82; Harris, supra note 179; Watts, supra note 178, at 710-11.

${ }^{182}$ See Watts, supra note 178, at 709 ("Not surprisingly, controversy quickly enupted over what the media described as Sebelius's 'unprecedented' decision to override the FDA's science-based findings."); see Alastair J.J. Wood et al., The Politics of Emergency Contraception, 366 N. ENG. J. MED. 101, 101-102 (2005) ("[W]e called attention to the damage that the FDA was doing - both to its reputation as an impartial regulatory agency that made decisions on the basis of science, insulated from politics, and potentially to women's health.");

${ }^{183}$ See Sherley v. Sebelius, 689 F.3d 776, 779 (D.C. 2012) (determining whether federal funding should be provided to "research projects directly involving the destruction of a human embryo and projects using embryonic stem cells derived from an earlier destruction"); see also Carbone \& Cahn, supra note 180, at 1016 ("The status of embryos, which involves profound religious and philosophical differences and which has become the subject of entrenched political differences over the course of the abortion fight, lies at the heart of these developments."); Jennifier L. Enmon, Stem Cell Research: Is the Law Preventing Progress?, 2002 UTAH L. REV. 621, 637-42 (2002) (discussing the debate over the personhood of IVF clinics' excess frozen embryos); Sonia M. Suter, In I'itro Gametogenesis: Just.Another Way to Have Baby?, 3 J.L. \& BIOSCIENCES 87, 116-18 (2016) (discussing the issue of embryo destruction in the context of another form of assisted reproductive technology, in vitro gametogenesis).

${ }^{184}$ See Future of American Federalism, supra note 43, at 1112 ("Although the United States has not generally been thought to suffer from the same sort of 'democratic deficit' that haunts European discourse, we are experiencing profound frustration with gridlocked and nonresponsive government in Washington, reflected in the precipitous decline in public trust in national goveming institutions.").

${ }^{185}$ Miriam Seifter, Further from the People? The Puzzle of State Administration, 93 N. Y.U. L. REV. 107, 14647 (2018) ("[S]cholars, courts, and policymakers . . tend to agree that states are closer to the people in some way that matters. In particular, the traditional praise for proximity suggests that it makes state governments more responsive to their constituents' desires or deters abuses of state power, or both." (citations omitted)); see The President, Executive Order No. 13132, Federalism (Aug. 4, 1999), 64 Fed. Reg. 43,255, 43,255-56 (Section 2. "Fundamental Federalism Principles[:] In formulating and implementing policies that have federalism implications, agencies shall be guided by the following fundamental federalism principles: (a) 
deficits" that exist in the state levels, many state legislators are responsive to citizen concerns, albeit with certain biases. ${ }^{186}$

The article observes that the process for approving mitochondrial transfer is swifter (and more concrete) in the United Kingdom than in the United States because in the U.K., the agency responsible for drafting regulations related to the issue conducted a public consultation regarding the scientific and ethical issues surrounding the procedure. ${ }^{187}$ In contrast, the United States has avoided using the standard administrative legal process and public consultations in general when new ART techniques are at issue. ${ }^{188}$ While this approach led to innovation in ART in the past, as traditional ART developed during the use of a minimally restrictive govemance framework, the same has not occurred as it relates to ART techniques involving inheritable genetic modifications in the United States. ${ }^{189}$ While there has been an ongoing global discussion of the impacts of germline editing and a robust public discussion in the United Kingdom of both the impacts of heritable genetic modifications and ART in general, the American experience has been marked by a more limited national conversation regarding the impacts of ART and heritable genetic modifications. ${ }^{190}$ The national conversation has largely been limited to a National Academy of Sciences report and conversations among employees of the Executive Branch, which includes the FDA, and has failed to include the larger American public. ${ }^{191}$ Further, funding restrictions implemented by Congress

Federalism is rooted in the belief that issues that are not national in scope or significance are most appropriately addressed by the level of government closest to the people.... (d) The people of the States are free, subject only to restrictions in the Constitution itself or in constitutionally authorized Acts of Congress, to define the moral, political, and legal character of their lives. (e) The Framers recognized that the States possess unique authorities, qualities, and abilities to meet the needs of the people and should function as laboratories of democracy.").

${ }^{186}$ See Micah Gell-Redman et al., It's All About Race: How State Legislators Respond to Immigrant Constituents, 71 POL. RES. Q. 517, 527-28 (2018); Kim Q. Hill \& Jan E. Leighley, The Policy Consequences of Class Bias in State Electorates, 36 AM. J. POL. SCI. 351, 363 (1992); but see Seifter, supra note 185, at 14650.

1872013 ANNUAL REPORT, supra note 83, at 4 ("The dialogue, entitled 'Medical Frontiers: debating mitochondrial replacement', was carried out over a period of six months, where we took the public temperature on this important and emotive issue. Our consultation showed broad support for mitochondrial replacement being made available to families with serious inherited mitochondrial diseases, provided the techniques are safe enough to use in the clinic and are well regulated.").

${ }^{188}$ See supra Part III.B.1; see also Subterranean Regulation, supra note 5, at 1241-45 (2018) (discussing the FDA's issuance of Untitled Letters to providers of forms of assisted reproductive technology involving genetic modifications)

${ }^{189}$ See supra Part III; see also Lars Noah, Assisted Reproductive Technologies and the Pitfalls of Lnregulated Biomedical Innovation, 55 FLA. L. REV. 603, 617-18 (2003) ("Unlike other medical technologies, ARTs arrive on the scene with little or no rigorous testing of their safety and effectiveness.").

190 See Jordan Paradise, U.S. Regulatory Challenges for Gene Editing, 13 SCITECH LAWYER 10, 11 (2016); International Summit on Human Gene Editing, NAT'L ACADS. OF SCI., ENG'G, \& MED., http://nationalacademies.org/gene-editing/Gene-Edit-Summit [https://perma.cc/9JUF-74CX] ("A major component of the National Academy of Sciences and the National Academy of Medicine's Human GeneEditing Initiative is an international summit that took place December 1-3, 2015, in Washington, D.C. Cohosted with the Chinese Academy of Sciences and the U.K.'s Royal Society, the summit convened experts from around the world to discuss the scientific, ethical, and governance issues associated with human geneediting research."); Second International Summit on Human Gene Editing, NAT'L ACADS. OF SCI., ENG'G, \& MED., http://www. nationalacademies.org/gene-editing/2nd summit [https://perma.cc/P6C4-KXZ5].

${ }^{191}$ See sources cited supra notes 148-50 and accompanying text (discussing the FDA's approach to political and social concerns that "have the potential to affect regulatory decisions."); see also NAT'L ACADS. OF SCIS., Eng. \& Med., Mitochondrial Replacement TeChniQues: Ethical, Social, and Policy CONSIDERATIONS 150 (2016). For more on the study approach, see id. at 3,24; see also R. Alta Charo, Dealing with Dolly: Cloning and the National Bioethics Advisory Commission, 38 JURIMETRICS J. 11, 11-14 (1997) (discussing the roles of "public bioethics commissions," including presidential bioethics commissions); M. 
have created an environment in which, even if the hurdle created by the actions of those employed by administrative agencies was removed, these techniques would still face significant obstacles to federal approval in the U.S. ${ }^{192}$

As a matter of outcome, there are also practical implications to the United States' democratic deficit in ART, which has culminated in a restrictive regime that hinders access to advanced assisted reproductive technologies. As seen in instances of cytoplasmic transfer ${ }^{193}$ in the United States, when the technique is not available in the United States, those with economic means are able to obtain it abroad, like the patients of the aforementioned Dr. Zhang who traveled to Mexico in order to obtain mitochondrial transfer from a U.S.-based physician in contravention of federal restrictions. ${ }^{194}$ This response raises the issue of "reproductive tourism." ${ }^{195}$ Many scholars have noted that FDA approval is often a precursor to insurance coverage of a treatment. ${ }^{196}$ Further, this is especially relevant in the realm of ART where a small number of states mandate coverage of ART services. ${ }^{197}$ Thus, to the extent that the FDA fails (or refuses) to approve these techniques in the United States, it could contribute to the gap in healthcare between those who are well-off, and can pursue treatments without

Cathleen Kaveny, Rhetoric, Public Reason and Bioethics: The President's Council on Bioethics and Human Cloning, 20 J.L. \& POL. 489, 491-94 (2004); John P. Holdren, Note on Genome Editing, THE WHITE HOUSE OFFICE (May 26, 2015), https://obamawhitehouse. archives.gov/blog/2015/05/26/note-genome-editing [https://perma.cc/P4PD-RE7Z] ("The White House fully supports a robust review of the ethical issues associated with using gene-editing technology to alter the human germline. The Administration believes that altering the human germline for clinical purposes is a line that should not be crossed at this time.").

${ }^{192}$ See Rob Stein, Babies With Genes From Three People Could Be Ethical, Panel Says, NPR (Feb. 3, 2016), http://www.npr.org/sections/health-shots/2016/02/03/465319186/babies-with-genes-from-three-peoplecould-be-ethical-panel-says [https://perma.cc/T4DZ-AXK7] (discussing the National Academies of Sciences, Engineering and Medicine report on cytoplasmic transfer); Statement on NIH Funding of Research Lsing Gene-Editing Technologies in Human Embryos, NAT'L INST. OF HEALTH (Apr. 29, 2015), https://www.nih.gov/about-nih/who-we-are/nih-director/statements/statement-nih-funding-research-usinggene-editing-technologies-human-embryos [https://perma.cc/7KGM-AHV3] (indicating that the NIH will not fund any use of gene-editing technologies in human embryos."). While gene editing and mitochondrial transfer are different techniques and research involving mitochondrial transfer is arguably further ahead due to its actual clinical use in the U.K. (and the use of it by U.S. doctors abroad), the social and ethical issues posed by genetic modification exist for both technologies.

${ }_{193}$ Ooplasmic/Cytoplasmic Transfer, CTR. FOR GENETICS \& SOC'Y, https://www.geneticsandsociety. org/ internal-content/ooplasmiccytoplasmic-transfer [https://perma.cc/UBG9-RP22] (defining cytoplasmic transfer as "an experimental fertility technique that involves injecting a small amount of ooplasm from eggs of fertile women into eggs of women whose fertility is compromised. The modified egg is then fertilized with sperm and implanted in the uterus of the woman attempting to achieve pregnancy.").

${ }^{194}$ See Zhang, supra note 116 and accompanying text.

${ }^{195}$ See Lisa C. Themoto, Reproductive Tourism: Equality Concerns in the Global Market for Fertility Services, 27 J. L. \& INEQUALITY 277, 277-79 (2009) (discussing the practice of "reproductive tourism," and those who travel to access fertility treatments); Kimberly M. Mutcherson, Welcome to the Wild West: Protecting Access to Cross Border Fertility Care in the Lnited States, 22 CORNELL J. L. \& PUB. POL'Y 349, 349-50 (2012) (discussing "cross border fertility care").

${ }^{196}$ See, e.g., Rachel E. Sachs, Delinking Reimbursement, 102 MINN. L. REV. 2307, 2309, 2314-21 (2018) ("Although there is not always perfect agreement between the set of FDA-approved drugs and the drugs payers are required to cover, in general there is significant overlap. Particularly for public payers, this robust coverage of prescription drugs is required by federal law. Although private payers are often less constrained, many of them provide similarly comprehensive prescription drug coverage pursuant to federal and state laws.").

${ }^{197}$ See King, supra note 27, at 313 n. 142 (discussing access to assisted reproductive technologies, disparities in access to ART, and states that mandate insurance coverage of ART); Falloon \& Rosoff, supra note 157, at 63-64 (discussing barriers to access to assisted reproductive technology that exist even with insurance coverage). 
insurance coverage, and those who cannot. ${ }^{198}$ As such, under this democratic deficit, disparities continue to exist not only with respect to the experience of U.S. patients as compared to those in other countries, but also with respect to experiences of patients within the United States, where some patients will be able to travel to access innovations in ART and others will not. ${ }^{199}$

States have also enacted legislation related to embryonic stem cell research, with some states encouraging it, and others banning it. ${ }^{200}$ As a matter of funding, in response to actions at the federal level that have precluded innovation by limiting the availability of research funding, some states, like California, have used representative democracy to identify state goals for innovation, such as the California Institute for Regenerative Medicine which was created aftera referendum ${ }^{201}$ and New York's Empire State Stem Cell Trust Fund which was created through State Finance Law. ${ }^{202}$ State coverage of stem cell research is relevant because it implies that there was some democratic input into the funding process at the state level whereas at the national level, the Executive and Legislative Branches (through budget riders) tend to exercise control over research funding involving techniques that are accompanied by ethical controversy. ${ }^{203}$ The New York Stem Cell Fund has contributed to research related to mitochondrial transfer. ${ }^{204}$ In turn, this state-funded research has contributed to the international discourse on ART techniques involving inheritable modifications. ${ }^{205}$ In other words, where there is limited federal funding, the private sector and states may respond in furtherance of innovation.

\footnotetext{
198 See Judith F. Daar, Accessing Reproductive Technologies: Invisible Barriers, Indelible Harms, 23 BERKELEY J. GENDER L. \& JUST. 18, 22, 31-32, 36-39 (2008) (discussing political, socioeconomic, and racial barriers to accessing assistive reproductive treatment)

199 See I. Glenn Cohen, Circumvention Tourism, 97 CoRnell L. REv. 1309, 1311-12, 1323-26 (2012) (discussing "medical tourism" in the context of assisted reproductive technology, in addition to "circumvention tourism," a subset of medical tourism).

${ }^{200}$ Enmon, supra note 183, at 641-47 (discussing various state statutes affecting embryonic stem cell research). 201 About CIRM, CAL. INST. FOR REGENERATIVE MED. (2018), https://www.cirm.ca.gov/ [https://perma.cc/QG7T-F5XH].

202 Frequently Asked Questions About NYSTEM, N.Y. STATE, https://stemcell.ny.gov/node/191 [https://perma.cc/Y3TX-9LEH]. For more on state stem cell initiatives, see CONGRESSIONAL RESEARCH Serv., Stem Cell Research: State Initiatives 2-8 (2006), https://stemcells.nih.gov/staticresources/research/GW-State-Funding.pdf; State Initiatives for Stem Cell Research, NAT'L INST. OF HEALTH, https://stemcells.nih.gov/research/state-research.htm [https://perma.cc/CS82-9FKJ].

${ }^{203}$ See Sebelius, 689 F.3d at 780 (discussing the role of Presidents George W. Bush and Barack Obama in providing guidance to the National Institutes of Health on the funding of stem cell research); see also Calandrillo \& Deliganis, supra note 77, at 313.

${ }^{204}$ See Jeff Lyon, Sanctioned LK Trial of Mitochondrial Transfer Nears, 317 JAMA 462, 463 (2017) ("The HFEA hesitated last summer when major players in the drive to bring MRT to fruition published work that included some qualms. The first article last June in Cell Stem Cell described an in vitro experiment in which Dieter Egli, PhD, and his colleagues at the New York Stem Cell Foundation sought to determine what happens to the minute amount of maternal mtDNA that inevitably hitches a ride when researchers create an embryo with the mother's nDNA and the donor's healthy mtDNA.").

${ }^{205}$ Id. Additionally, just as states have provided funding of stem cell research in the absence of governmental funding, private organizations (including professional organizations) have also provided funding for assisted reproductive technology research. See Am. Soc. for Reproductive Med., American Society for Reproductive Medicine Announces Major Research Initiative-Creation of the ASRM Research Institute, a $\$ 10$ Million Startup Investment for the Future of Reproductive Medicine, ASRM BULLETIN (Jun. 12. 2018), https://www.asrm.org/news-and-publications/news-and-research/press-releases-and-bulletins/americansociety-for-reproductive-medicine-announces-major-researchinitiative/?_ga=2.228771932.114722499.1545121639-1132316020.1545121639 [https://perma.cc/CAA28R5L].
} 
The U.S. experience with ART, primarily at the federal level, highlights the lack of transparency and public participation in the administrative process even though the administrative legal process was structured to further these goals. ${ }^{206}$ As a result, states are making up for the lack of public participation in federal administrative law. ${ }^{207}$ The next section crafts solutions based on a number of disciplines, notably administrative law and health law, to the American democratic deficit in ART innovation.

\section{ADAPTING THE TOOLS OF ADMINISTRATIVE LAW TO MINIMIZE THE U.S. DEMOCRATIC DEFICIT IN ASSISTED REPRODUCTIVE TECHNOLOGY INNOVATION}

The solutions in this section could minimize the American democratic deficit in ART and also hasten the implementation of forms of ART involving genetic modification. These recommendations draw on scholarship in administrative law and examples of successful approaches, including the UK's experience with mitochondrial transfer and state experiences with stem cell research funding and legislation. Part A examines and critiques the possibility of an independent federal agency in the United States that would regulate ART use, whereas parts B-D examine the UK's five-strand public discourse on mitochondrial transfer and methods of adapting public discourse into the American administrative state.

\section{A. An INDEPEndent Federal Agency in the U.S.}

While other scholars have argued for an independent federal agency to regulate ART, this article does not advocate for that approach. ${ }^{208}$ Many of the scholars who do advocate for an independent federal agency build on the example of the HFEA. ${ }^{209}$ Yet, despite the similarities between the United States and the United Kingdom, many differences between the two would make the creation of such an independent federal agency addressing ART both unlikely and unfeasible. First, religious opposition to ART and the medical industry's general opposition to increased regulation would make it difficult to create such an agency. ${ }^{210}$ Second, logistically, even

\footnotetext{
${ }^{206}$ See Bierschbach \& Bibas, supra note 162, at 23 ("Participation . . enhances the soundness of agency decisions by improving the quality and variety of the information an agency considers, whether empirical or related to the public's preferences. It improves accountability by obligating agencies to justify their actions publicly ... It increases public trust and educates citizens in government affairs, creating feedback loops between agencies and citizens. And, ... it bolsters agency decision-making's democratic pedigree." (citations omitted)); Marchant, supra note 20, at 256.

${ }^{207}$ See Nina Mendelson, A Presumption Against Agency Preemption, 102 Nw. U. L. REV. 695, 709 (2008) ("Second, federalism, including a state's enactment of its own laws, also may stimulate citizen participation in self-governance, on the theory that it is easier to participate at a level of government closer to one's home."); but see Frank Cross, The Folly of Federalism, 24 CARDOZO L. REV. 1, 1-2 (2002) (suggesting that "federalist" values are really values of localism). While much of the administrative law scholarship focuses on administrative law at the national level, states also have administrative agencies. For more on state participation in the federal administrative law process and the implementation of federal programs, see generally, Seifter, supra note 155. For more on the operation of administrative law at the state level, see Michael Asimow, Contested Issues in Contested Cases: Adjudication Linder the 2010 Model State Administrative Procedure Act, 20 WDENER L.J. 707, 707-13 (2011); Seifter, supra note 185, at 131-48; Michael Asimow, The Imfluence of the Federal Administrative Procedure Act on California's New Administrative Procedure Act, 32 TULSA L. J. 297, 298-303 (1996); Seifter, supra note 185, at 131-48. .

${ }^{208}$ See King, supra note 27, at 169-70.

${ }^{209}$ See id. at 169 (referring to "the HFEA indications approach").

${ }^{210}$ Robert Gatter, Faith, Confidence, and Health Care: Fostering Trust in Medicine Through Law, 39 W AKE FOREST L. REV. 395, 440 (2004); William M. Sage \& David A. Hyman, Combating Antimicrobial Resistance:
} 
if such an agency was created, significant effort would likely have to be exerted in order to figure out how that agency and the FDA, which has been regulating ART involving genetic modification and the drugs and devices used in ART treatments would share jurisdiction, if at all. Additionally, if funding restrictions imposed by Congressional budget riders continued to exist, then an HFEA-like agency would have to decide how the National Institutes of Health would fit into the regulatory framework. Further, an independent federal agency would still remain subject to political pressure and budgetary control by Congress and the President. ${ }^{211}$ Additionally, while Congress could introduce an act to seize power from the states, who have regulated (or failed to regulate, depending on one's point of view) ART, giving the federal government more power over reproductive issues (and by implication, reproductive rights and the practice of medicine), this in general does not resolve the issue of who should be regulating ART. Additionally, from the perspective of strengthening reproductive rights (or maintaining the status quo), is likely undesirable. ${ }^{212}$ Beyond that, the myriad of issues surrounding ART, especially in a country that has failed to have a national public discourse on traditional ART, would not be resolved by the creation of an HFEA-like agency.

B. Adapting the UK's Public Consultation on Assisted Reproductive TECHNOLOGY TO THE U.S. REgulatory REgIME

Many aspects of the UK's public consultation on mitochondrial transfer would fit into the United States' existing federal regulatory framework governing ART. Just as notice-and-comment rulemaking can improve public participation in the administrative process, so can other methods of promoting the inclusion of public views in the agency regulatory process. ${ }^{213}$ In fact, many of the aspects of the UK's public consultation on mitochondrial transfer are similar to actions that the HHS has already undertaken for other issues. ${ }^{214}$

For example, when determining the meaning of essential health benefits, the HHS allowed individual states to set that benchmark. ${ }^{215}$ Before issuing the document that announced this decision, HHS undertook a number of methods of outreach with

Regulatory Strategies and Institutional Capacity, 84 TUL. L. REV. 781, 815 (2010) (discussing self-regulation in healthcare); but see John A. Robertson, Assisted Reproductive Technology and the Family, 47 HASTINGS L.J. 911, 920 (1996) (noting that the American Society for Reproductive Medicine would be amenable to an HFEA-like agency that would license and inspect fertility clinics, whereas the author, Professor John Robertson, is skeptical of the creation of such an agency); Robertson, supra note 24, at 1035-36 ("With adequate peer involvement, more explicit legal controls, such as the national licensing authority suggested in the Warnock Report, need not take root in American soil.").

${ }^{211}$ Kirti Datla \& Richard L. Revesz, Deconstructing Independent Agencies (and Executive Agencies), 98 CORNELl L. REV. 769, 808, 816 (2013); Neal Devins, Regulating of Governmental Agencies Through Limitations Riders, 1987 DUKE L. J. 456, 461 (discussing "appropriations as oversight").

${ }^{212}$ See King, supra note 27, at 173 (detailing the "five main functions" of a proposed "national independent regulatory body ... which would include at least two functions that would infringe on the practice of medicine: "1) establish a licensing system for ART clinics; 2) establish procedural guidelines and regulations for ART practice; ...5) in the case that proven risks outweigh the benefits for certain procedures, regulate the use of PGS for certain indications using the novel balancing framework proposed above."); see also Cahn \& Carbone, supra note 180, at 380 (discussing "how politics at the national level can affect access to reproductive rights"). ${ }^{213}$ Bierschbach \& Bibas, supra note 162, at 20.

214 See HHS Agencies \& Offices, U.S. Dep'T OF HeAlth \& Human Servs. (Oct. 27, 2015), https://www.hhs.gov/about/agencies/hhs-agencies-and-offices/index.html [https://perma.cc/S32Y-UK7V] ("HHS has 11 operating divisions, including eight agencies in the U.S. Public Health Service and three human services agencies."); id. (noting that the FDA is an operating division within the U.S. Department of Health and Human Services).

${ }^{215}$ Nicholas Bagley \& Helen Levy, Essential Health Benefits and the Affordable Care Act: Law and Process, 39 J. HEALTH POL., POL'Y, \& L. 441, 442, 447-49 (2014). 
states and other stakeholders, including the public with whom the agency interacted through "a series of "listening sessions." ${ }^{216}$ Professors Bagley and Levy note that HHS had no obligation to undertake such an inclusive approach under the Administrative Procedure Act's notice-and-comment requirements. ${ }^{217}$ Yet, such an inclusive process would greatly improve the regulation of advanced assisted reproductive technologies in the United States. Granted, the example of deciding what would be included in the term "minimum essential health benefits" is not a perfect parallel to ART innovation. While it is likely that ethical and political views on reproduction and women's health surfaced, those ethical views were not the same as those involved in regulating traditional ART and advanced assisted reproductive technologies. ${ }^{218}$ Nonetheless, the format of these "listening sessions" could be used in public discourse related to a number of other health-related issues, including ART.

The listening sessions held by HHS are similar to the second and third strands of the UK's public consultation, which included face-to-face interviews with members of the public. ${ }^{219}$ As it is, U.S. administrative agencies already conduct "public meetings" in which they explain regulatory decisions; therefore, the structure for something analogous to the second strand of the UK's public consultation already exists. Additionally, agencies are staffed by scientific (and technical staff). Thus, agencies already employ individuals who, like those who provided explanations to members of the public of the science underlying mitochondrial transfer in the first strand of the UK public consultation, could explain to the American public the techniques involved in mitochondrial transfer. ${ }^{220}$ The FDA, for example, already has a "Grand Rounds" program in which FDA scientists "present[] on a key public health challenge and how FDA is applying science to its regulatory activities." 221 The FDA could expand this Grand Rounds Program and expand its format into the agency's public meetings, were it to participate in a public discourse on mitochondrial transfer.

Another option is to increase the visibility of the array of ethical and social viewpoints on ART in order to address the current situation in which the positions of politicians have been serving as proxies for the viewpoints of members of the American public. The current point of reference in the U.S. for ethical issues related to new forms of ART is driven by the feelings or beliefs of politicians and employees in the federal legislative and executive branches, yet no one has asked the American public whether it has an opinion on forthcoming medical innovations and their permissibility. ${ }^{222}$ These

${ }^{216} I d$. at $445,449$.

${ }^{217}$ Id. ("The agency had no obligation to do any of this public outreach. Without informing anyone of its thinking, HHS could simply have issued a notice of proposed rulemaking announcing the benchmark approach. After receiving comments and issuing a final rule, HHS would then have complied with all of the APA's notice-and-comment requirements."); id. at 456 (noting that "agencies do not have to solicit feedback on guidance documents.").

${ }^{218}$ Cf. Burwell v. Hobby Lobby, 573 U.S. 682 (2014). Thus, while ethical views may not have prevented the inclusion of contraception in minimum essential health benefits at the level of the administrative agency's decision making, the ethical views, which would be religious views in the Hobby Lobby case, of those who would be subsidizing the insurance plans required to have minimum essential health benefits are entitled to a certain amount of exemption or waiver by the federal government.

219 See FDA Grand Rounds, U.S. FOOD \& DRUG ADMIN. (Dec. 20, 2018), https://www.fda.gov/scienceresearch/aboutscienceresearchatfda/ucm486711.htm [https://perma.cc/9LNGWGXH].

220 See supra note 105 and accompanying text (explaining the first strand of the UK's public consultation on mitochondrial transfer).

${ }^{221}$ See FDA Grand Rounds, supra note 219

${ }^{222}$ Stein, supra note 192 ("But [Dr.] Sauer said he was disappointed when he learned of the FDA's response 'Politics as usual often gets in way of progress," Sauer said in a subsequent email. While the FDA statement 
political feelings or beliefs manifest not only through public statements, but also regulatory actions that have not been subject to judicial review, such as funding restrictions, budget riders and non-interpretive documents issued by administrative agencies. ${ }^{223}$ As such, another option could be to use rulemaking to address the issue of federal regulation of ART using a rule instead of informal documents, as doing so could also facilitate the deliberative public process that is currently missing in the federal regulation of ART. ${ }^{224}$

In 2016, Professor Barbara Evans wrote that "[i]t is time to insist on evidencebased bioethics." 225 Again, the UK's public consultation could serve as a model for the United States. For example, the UK asked members of the public what their views were on the ethical considerations related to mitochondrial transfer and then tracked whether their views changed after the concept was further explained to them. ${ }^{226}$ Implementing something similar in the United States would be a way to institute evidence-based bioethics. ${ }^{227}$ Considering the role of states, outside of the bioethics literature other professors have noted that "experimentation may help clarify the ideological space."228 In the area of stem cell research, state involvement has already created an experimental ideological space where state laws and funding decisions are proxies for the views of the public. ${ }^{229}$ At the federal level, using patient focus groups, for example, as the UK did in the fifth strand of their public consultation, would allow members of the public to provide input on the "moral, ethical, and social policy issues related to genetic modification of eggs and embryos ...that ... have the potential to affect regulatory decisions. ${ }^{230}$

\section{Greater Disclosure: Separating Scientific Concerns from Political AND ETHICAL CONCERNS}

Many scholars have written in favor of more disclosure and transparency within the administrative law and health law literatures. ${ }^{231}$ Professor Nina Mendelson,

["prais[ed] the 'thoughtful work' of the panel and said the agency would be 'reviewing' the recommendations of the 2016 Institute of Medicine Panel] ... [since then] . . the latest federal budget 'prevents the FDA from using funds to review applications in which a human embryo is intentionally created or modified to include' changes that could be passed down to future generations... any such research 'cannot be performed in the United States' at this time"]."] ... [This] would cause 'undue delays' in his research, he added that he hoped it wouldn't permanently 'necessarily halt the efforts."').

${ }^{223}$ See FDA Letter, supra note 119 (noting that the FDA had jurisdiction over the mitochondrial replacement techniques used by Dr. John Zhang and also noting that, pursuant to the Consolidated Appropriations Act, the FDA could not use "funds to accept IND submissions for clinical investigations that involve "a human embryo ... intentionally created or modified to include a heritable genetic modification."').

${ }^{224}$ See Aaron L. Nielson, Sticky Regulations, 85 U. CHI. L. REV. 85, 88, 94 (2018).

${ }^{225}$ Barbara J. Evans, The Evolving Ethics Challenge in Genomic Science, 13 SCITECH LAWYER 1, 24 (2016).

226 See supra Part III.

${ }^{227}$ Evans, supra note 225.

${ }^{228}$ Michael Livermore, The Perils of Experimentation, 126 YALE L. J. 636, 674 (2017) ("But for new policy domains - for example, when stem cell research first arose as a policy question-experimentation may help clarify the ideological space."); see id. at 674 n. 118 ("Clarifying ideological space may be of value to society, depending on how that information is put to use. Even if the clarification is not socially valuable, it might still be valuable to political actors.")

${ }^{229}$ See Nefi D. Acosta \& Sidney H. Golub, The New Federalism: State Policies Regarding Embryonic Stem Cell Research, J. LAW MED. \& ETHICS 419, 419 (2016).

${ }^{230}$ MEETING \#59 TRANSCRIPT, supra note 148, at 13; see sources cited supra note 111 and accompanying text (providing the fifth strand of the UK's public consultation on mitochondrial donation).

${ }^{231}$ See Evan J. Criddle, Fiduciary Administration: Rethinking Popular Representation in Agency Rulemaking, 88 TEx. L. REV. 441, 478 (2010) (discussing the value of transparency in administrative law); Elizabeth Y. 
for example, has argued for greater disclosure of the role of executive supervision in agency decisions. ${ }^{232}$ One hope is that greater disclosure of the role of executive or political pressure in agency decisions might lead to a more deliberative democracy where agency employees disclose to what extent their views are, as evidenced by for example, the FDA's decisions related to the prescription over-the-counter switch of Plan $B$, actually based on safety and efficacy and not factors outside of the agency's statutory mandate, such as political pressure. ${ }^{233}$ Further, a significant amount of the FDA's decision-making process occurs outside of the public's view and "documents exchanged between the FDA and a drug sponsor during the back-and-forth over a new drug application are not made public, often not even after the application is approved." ${ }^{234} \mathrm{In}$ other words, to the extent that political pressures, moral concerns, or social policy views are being incorporated into the decision-making process, they should be disclosed. ${ }^{235}$ This article takes a similar approach as, in the realm of assisted reproduction, scientific and social concerns often overlap, even though the FDA is an agency that is supposed to regulate for safety and effectiveness. ${ }^{236}$ For example, in the realm of cloning (which is not an ART, as it does not so much involve reproduction as replication), the FDA stated that not only did the procedure require an investigational new drug application, but also that the FDA would not accept any applications due to unresolved safety concerns, yet the agency did not identify those concerns. ${ }^{237}$ In the instance of the FDA's original failure to approve Plan B for use in all women of childbearing age, the agency seemed to also muddle social concerns with safety concerns. ${ }^{238}$ The FDA has undertaken a similar approach to forms of ART involving genetic modification. For example, with respect to cytoplasmic transfer, the FDA reportedly told one researcher, who engaged with them after receiving a letter stating that the technique would require an investigational new drug application, that the researcher would have to prove that the technique was safe. ${ }^{239}$ The agency could not, however, tell the researcher what studies

McCuskey, Agency Imprimatur \& Health Reform Preemption, 78 OHIO ST. L.J. 1059, 1162 (2017) ("The agency imprimatur model has the potential to imbue health law federalism decisions with more transparency and public participation opportunities than judicial preemption decisions afford.").

${ }^{232}$ Mendelson, supra note 40, at 1130-31, 1163-65, 1169.

233 James T. O'Reilly, Losing Deference in the FDA's Second Century: Judicial Review, Politics, and a Diminished Legacy of Expertise, 93 CORNELL L.REV. 939, 964-67 (2008); Watts, supra note 178, at 732.

${ }^{234}$ Heinzerling, supra note 177 , at 938 .

${ }^{235}$ Mendelson, supra note 40, at 1130-31, 1163-65.

23621 U.S.C. § 393(b)(2) (2012).

${ }^{237}$ See Subterrane Regulation supra note 5, at 1257, 1292-93 (providing FDA's view on the regulation of human cloning in the United States); see also, Therapeutic Cloning and Genome Modification, Cellular \& Gene Therapy Products, U.S. FOOD \& DRUG ADMIN. (Mar. 16, 2018), https://www.fda.gov/biologicsbloodvaccines/cellulargenetherapyproducts/ucm2007205.htm ("In March 2001, FDA sent a letter to the research community asserting regulatory authority over clinical research using cloning technology to create a human being, and to advise that FDA regulatory process is required in order to initiate these investigations. FDA jurisdiction includes human cells used in therapy involving the transfer of genetic material by means other than the union of gamete nuclei. Examples of such genetic material include, but are not limited to: cell nuclei (for cloning), oocyte nuclei, ooplasm, which contains mitochondria and genetic material contained in a genetic vector, transferred to gametes or other cells. Any clinical research involving these techniques would require an IND.").

${ }^{238}$ Wood et al., supra note 180, at 1197-98 ("The stated reason is that there is uncertainty about the drug's safety in younger women. But the FDA has not pointed to any data support that position, nor has the agency demanded such evidence in the case of other drugs that have been switched to over-the-counter status. All involved acknowledge that Plan B is extraordinarily safe.").

${ }^{239}$ Connor, supr note 6 (noting that FDA employees could not tell him what he needed to do in order to establish safety and that the "animal literature established, as well as you can establish, safety ... [as such] . . 
would be required in order to prove that the technique was safe. ${ }^{240}$ Considering the FD A's statutory mandate, which is to evaluate products for safety and effectiveness, the agency should be able to articulate to prospective applicants what would satisfy its interpretation of the safety and effectiveness requirements of its enabling statute. ${ }^{241}$ Not doing so causes the public to question "the integrity of the [regulatory] process," and for those in the medical profession, "[i]t is also likely to mean that both physicians and patients will wonder whether future drug-approval decisions are based on the evidence with regard to efficacy and safety or, rather, on, political considerations. How will we know? How will we find out?" 242

These concerns regarding the integrity of the regulatory process undermine administrative law's goals of accountability and legitimacy. ${ }^{243}$ While the public was able to ascertain the existence of decision-making outside of the statutory mandate in the instance of Plan B, it required federal litigation (that included discovery beyond what the public would have been able to obtain through Freedom of Information Act requests) and a GAO report. ${ }^{244}$ The experience of the FDA in regulating other forms of ART involving genetic modification indicates that it is possible that the FDA continues to succumb to political and social pressures in the regulatory process, yet the public lacks an opportunity to ascertain whether that is the case. Increasing the use of deliberative democracy in the decision-making process would increase the opportunity for the public to ascertain what underlies the agency's decision-making and also, to the extent that political or social views are being considered in the regulatory process, create an environment for a more thorough and fair consideration of social and political views, with transparency.

In light of the UK's robust analysis of the underlying safety and effectiveness of mitochondrial transfer, using the UK's five-strand consultation could aid the FDA in separating its safety analysis from its social analysis. ${ }^{245}$ Drawing from the UK's analysis would allow the FDA to categorize exactly which aspects of its regulatory decisionmaking corresponds to (1) safety, (2) effectiveness, and (3) political, social, and ethical considerations. For example, the public consultation in the UK revealed that many individuals' concerns surrounded the safety of the techniques and that "[s]ometimes, safety concerns become a proxy for concerns about ethical and social issues, which are often hard to express. On other occasions, support for mitochondria replacement dipped when the scientific evidence was less clear." 246 In the leadup to the approval of mitochondrial transfer in the United Kingdom, the HFEA conducted multiple reviews of the scientific and safety issues related to the use of mitochondrial transfer, where it examined the existing medical literature and current research, including that of U.S.based scientists. ${ }^{247}$ The example of the UK's approval of mitochondrial transfer, which included a safety and scientific review, in addition to a public consultation and an assessment of social and ethical considerations, indicates that safety and science

\footnotetext{
. you can never say 'it's safe' until you do it."); see supra note 104 and accompanying text (providing the similar view of the UK's Chief Medical Officer on the use of mitochondrial transfer in humans).

240 Connor, supra note 6.

24121 U.S.C. § 393(b)(2) (2012).

${ }^{242}$ See Jeffrey M. Drazen et al., The FDA, Politics, and Plan B, 350 N. ENG. J. MED. 1561, 1561-62 (2004);

Wood et al., supra note 180, at 1199.

${ }^{243}$ See Drazen et al., supra note 242, at 1561 (20040; Watts, supra note 179, at 708, 726.

${ }^{244}$ Heinzerling, supra note 177 , at 952.

${ }^{245}$ See ADVICE TO GOVERNMENT, supra note 93 , at 7.

${ }^{246} \mathrm{Id}$. at 15

${ }^{247}$ See infra Part III; see also supra note 101 and accompanying text (citing to the UK's four publications on the science and safety of mitochondrial transfer).
} 
analyses can be separated from ethical, social, and political concerns. Applying the lessons of the U.K.'s experience with the approval of mitochondrial transfer, the FDA should clearly state which aspects of current and forthcoming ART and advanced assisted reproductive technologies implicate scientific concerns and which aspects implicate social, political, and ethical considerations.

D. InCREASING THE Role OF THE STAtes

States have instituted a number of measures that address the deficit in deliberative democracy related to stem cell research and ART in the United States. Increasing the role of the states in the regulation of traditional ART and advanced assisted reproductive technologies flows naturally from the jurisdiction of states and their responses to democratic deficits in the regulatory process in the United States to date. As a jurisdictional matter, states already have historic police powers that empower them to serve as gatekeepers to the medical profession. ${ }^{248}$ Additionally, states have regimes to compensate citizens for certain harms suffered during medical treatment through tort regimes that provide for medical malpractice liability. ${ }^{249}$ Beyond creating liability regimes for damages incurred during medical treatment, states have also instituted regimes that recognize the results of ART use, whether of parentage or leftover embryos, through family law statutes and court decisions. ${ }^{250}$ Further, as a matter of funding, some states fund research that the federal govemment will not, with an emphasis on research that involves the destruction of embryos. ${ }^{251}$ At the same time, states have created statutory regimes that indicate what kind of research they will fund, with some states funding types of research that Congress would not and other states creating regimes with restrictions that are very similar to federal limitations. ${ }^{252}$ Nonetheless, the benefit of these state regimes is that they allow for more democratic participation by, at the very least, clearly signaling to the public that lawmakers are undertaking decisions related to these matters.

For those states that do choose to fund research and innovation that has been stymied by Congress, it could be useful for them to take on a stronger role in the gathering of information related to innovations in ART or medicine in general. For example, a common refrain of scientists whose research involves genetic modification is that society needs to decide whether it is desirable to undertake scientific innovations that involve inheritable genetic modifications. ${ }^{253}$ This is notable not only because it is a deviation from the often-undertaken effort of scientists and physicians to regulate themselves, but also because it represents a call by innovators to include societal views in science. ${ }^{254}$ Currently, the national govemment has failed to undertake this conversation, but states are well-placed to do so as an alternative to the current regulatory standstill in the absence of discourse, by virtue of their proximity to citizenry. ${ }^{255}$ Not only might states want to undertake this consultation on their own, but

${ }^{248}$ See Barry Furrow et al., Healthlaw: Cases, Materials, and Problems 87 (7th ed. 2013).

${ }^{249}$ See Daar, supra note 17 , at 615 .

${ }^{250}$ See id. at 624-26, 646; but see Courtney G. Joslin, Protecting Children(?): Marriage, Gender, and Assisted Reproductive Technology, 83 S. CAL. L. REV. 1177, 1178-81 (2010).

${ }^{251}$ See Alicia Ouellette et al., Lessons Across the Pond: Assisted Reproductive Technology in the Linited Kingdom and the Lnited States, 31 AM. J. L. \& MED. 419, 423, 436-37 (2005).

${ }_{252}^{25}$ See id. at 423.

253 See, e.g., Mary T. Bergman, Perspectives on Gene Editing, Harvard GAZETTE (Jan. 9, 2019), https://news.harvard.edu/gazette/story/2019/01/perspectives-on-gene-editing/ [https://perma.cc/3CFZ-336E] 254 Id.

${ }^{255}$ Seifter, supra note 185 , at 146-47. 
the federal government should consider whether it should actively encourage states to do so, as increasing the participation of states in the regulatory regime might not only encourage public involvement in the regulatory process, but also allow for experimentation. ${ }^{256}$

\section{CONCLUSION}

The article has focused on the American democratic deficit in ART and how states have made strides in correcting that deficit. For decades, the political discourse has remained at a standstill as legislators have refused to address questions related to the ethics of ART, especially those involving germline modification. Furthermore, those legislators have refused to address those questions through several actions including: (1) spending restrictions on applications that would involve such processes, (2) refusing to check administrative agency overreach, in spite of media and literature coverage, and (3) the disbanding of bioethics commissions.

While ethics certainly matter, the question of whether they should impact regulatory decision-making, instead of being left to the doctor-patient relationship (assuming all patient protections such as informed consent and patient protective bioethics principles exist), is a question for another article. ${ }^{257}$ Also, to the extent that there is a concern in the United States as to partisan politics affecting health care, individual rights, and science more broadly, expanding the use of democratic inputs, especially as it relates to federal decision-making that implicates reproductive rights, reproductive healthcare, and ultimately the ability of parents to decide what is best for their future children, adopting the solutions provided in this article might "... not only produce more effective policy but also increase the acceptability of the regulatory process." 258 Doing so would have implications not only for the administrative state, but also for the American public's impressions of the administrative state and the role of the federal government in affecting their everyday lives.

\footnotetext{
${ }^{256}$ While states currently license medical providers, another question that might be asked is whether the current demarcation of state and federal jurisdiction should remain as it is, especially in the realm of advanced assisted reproductive technologies. That normative issue is a topic for another paper. See Bagley, supra note 7, at 271 ("Even though regulation of health and safety is 'primarily, and historically, a matter of local concern,' there is no question that the Federal Government can set uniform national standards in these areas."(citations omitted)).

${ }^{257}$ See, e.g., King, supra note 27, at 107 (advocating "for the creation of an independent federal entity, the Assisted Reproductive Technology Authority (ARTA)").

${ }^{258}$ Rose-Ackerman, supra note 21, at 442.
} 